\title{
PEDRO PELÁEZ, LÍDER DEL CLERO FILIPINO
}

\author{
POR \\ RoBERTO BLANCO ANDRÉS \\ Doctor en Historia*
}

\section{RESUMEN}

En este trabajo se intentan aportar algunas claves y datos inéditos sobre la biografía del presbítero criollo filipino Pedro Pablo Peláez, que es, junto con el P. José Burgos, el eclesiástico más destacado de la iglesia de Filipinas del siglo XIX. El trabajo aborda la totalmente desconocida actividad del P. Peláez en el cabildo de la catedral de Manila, donde acabaría siendo con el tiempo su hombre más insigne. Igualmente se analiza el espíritu e ideario reformista de Peláez y sus trabajos y estrategia para defender al clero secular filipino, cuyos derechos estaban siendo vulnerados por una serie de Reales Órdenes (1848 ó 1861) y la actitud reaccionaria de un sector de las órdenes religiosas. Peláez supo articular un modus operandi minucioso y muy efectivo en torno a la legitimidad de los curas filipinos en la dirección de las parroquias del país. Aunque sus actividades cesaron con su inesperada muerte en el terremoto de junio de 1863, Peláez se convirtió en una inspiración y un modelo a seguir.

PALABRAS CLAVE: secularización, sacerdotes nativos, órdenes religiosas, historia de la Iglesia, Filipinas

\section{PEDRO PELÁEZ, LEADER OF FILIPINO CLERGY}

\section{ABSTRACT}

This article provides new information on the creole Filipino, Fr. Pedro Pablo Peláez, who, together with Fr. José Burgos, was the most outstanding clergyman in the nineteenth-century Philippines. It discusses Father Peláez's previously

\footnotetext{
* Este trabajo se publica en el marco del Proyecto: «Imperios, naciones y ciudadanos en Asia y el Pacífico» HAR2009-14099-CO2-02». IH-CSIC.
} 
unknown activities in the cabildo of the Manila Cathedral, where he was its most distinguished member. It analyzes his reformist ideas, and explains his work and strategy to defend the Filipino secular clergy, whose rights were being violated by the royal orders of 1848 and 1861 . Against the reactionary religious orders, Pelaéz had a detailed modus operandi to defend the legitimacy of native priests' control of parishes. Although his activities were cut short by his unexpected death in the earthquake of June 1863, Peláez served as an inspiration to be emulated

KEY WORDS: secularization controversy, native priests, religious orders, church history

Recibido/Received 01-07-2009

Aceptado/Accepted 27-01-2011

Siempre me ha llamado enormemente la atención lo poco conocida que sigue siendo aún para los filipinos la figura del presbítero filipino Pedro Peláez. Y más aún, después de que desde el mismo siglo XIX en que vivió, y en el siglo siguiente hasta la actualidad, diversos estudiosos se hayan referido a él recordando su inmenso prestigio, su alta preparación, y su innegable influencia e incluso significación precursora en la gestación de la conciencia nacional durante el período español.

Sobre estos aspectos se manifestó el historiador jesuita, P. Jonh N. Schumacher, en varios de sus libros. El conocimiento de su obra me ha incitado a profundizar en el estudio de la iglesia hispano-filipina, y a buscar y rebuscar en múltiples archivos todo aquello que encontrase sobre el P. Peláez.

Estos años de estudio me han convencido de que sigue siendo realmente poco lo que se conoce sobre el Peláez histórico, más allá de los mitos propalados por cierta historiografía marcadamente nacionalista, así como la necesidad de seguir ahondando en su biografía y en su tiempo.

El presente artículo ofrece algunos de los resultados de esta investigación, intentando proporcionar datos inéditos sobre él y otros poco o nada conocidos junto a perspectivas y valoraciones de su significado en la misma historia de Filipinas.

\section{UNA CARRERA ECLESIÁSTICA JUNTO A LOS DOMINICOS}

Es muy escasa la información que tenemos sobre la infancia y juventud del P. Peláez. Tan sólo algunas notas dispersas sobre su formación y estudios, muchas veces sin concretar fechas y otras tantas incluso confundiéndolas. ${ }^{1}$ No

\footnotetext{
${ }^{1}$ Algunos datos biográficos elementales sobre Peláez en: Manuel ArTigas y Cuerva, Historia de Filipinas, Manila, Imp La Pilarica, 1916, 439-441; Carlos QuIRINO, «A checklist of Documents on 
obstante, el estudio de sus expedientes personales en el Archivo Histórico Nacional aporta datos más detallados y precisos.

Pedro Pablo Peláez nació en Pagsanjan (La Laguna) el día 29 de junio de 1812. Sus padres fueron Don José Peláez Rubio, natural del principado de Asturias (España) y alcalde mayor de la provincia, y Doña Josefa Sebastiana Gómez Lozada, natural de Manila. ${ }^{2}$ Seis días más tarde, el 5 de julio, fue bautizado por el P. Francisco Villegas, franciscano, ex definidor y cura párroco de la Iglesia de Nuestra Señora de Guadalupe de Pagsanjan. Fue su padrino el coadjutor de la misma parroquia, el bachiller Don Pedro Alcántara. ${ }^{3}$ En 1817 recibió el sacramento de la confirmación, siendo su padrino Don Manuel de los Reyes, oficial interventor de la Real Renta de Vinos.

Peláez quedó huérfano siendo aún un niño. Se desplazó pronto a Manila para estudiar en el colegio dominico de Santo Tomás. Desde 1823, y durante los doce años siguientes disfrutó de una beca y se destacó como alumno muy aventajado. ${ }^{4}$ Primero estudió Gramática Latina, Retórica, Filosofía y Sagrada Teología. Desde 1826 cursó tres años de Artes o Filosofía (Lógica, Física y Metafísica), al final de los cuáles obtuvo el 19 de febrero de 1829 el grado de bachiller con aplauso sincero de sus profesores. ${ }^{5}$ A continuación prosiguió con cuatro años de estudio de Teología, graduándose de bachiller el 21 de enero de

Gomburza from the Archidiocesan Archives of Manila», Philippine Studies 21 (1973); John N., ScHUMACHER, Revolutionary clergy. The Filipino Clergy and the nationalist movement. 1850-1903, Ateneo de Manila, University Press, 1981, 6-12; Antolín V. Uy, The State of the Church in the Philippines 1850-75, The correspondence between the bishops in the Philippines and the Nuncio in Madrid. Manila, Steyler Verlag St. Augustin, 1984.

${ }^{2}$ Algunos autores han referido el origen filipino en algún grado de la madre de Peláez. Sin desmentir este dato, lo cierto es que la documentación trabajada en el archivo siempre se refiere a Peláez como «español del país» (criollo).

${ }^{3}$ Copia del acta de bautismo entre los documentos personales incluidos en: AHN (Archivo Histórico Nacional), Ultramar, Filipinas, 2201, Gracia y Justicia, expediente 12.

${ }^{4}$ Agradezco el dato de la entrada en el colegio (1823), así como otros de su estudio y formación provenientes del archivo de la Universidad de Santo Tomás al P. Fidel Villarroel, dominico.

${ }^{5}$ Los dominicos se sintieron orgullosos de contar en sus aulas con un hombre como Peláez. En 1840, el P. Francisco Ayala, doctor en Teología y Derecho canónico, rector y cancelario de la Real y Pontificia Universidad y Colegio de Santo Tomás de Manila, decía que el joven de La Laguna se había destacado en la obtención de los grados de Bachiller «sobre los demás así en sus ejercicios de examen como en varios actos literarios de esta Universidad que ha merecido se le confiasen por su mucho despejo, claridad de ideas y abundancia de conocimientos» y que siempre había tenido «una conducta ejemplar e irreprensible en los doce años que fue alumno de este establecimiento (donde entró muy tierno) mereciendo así por su esmerada aplicación el estudio, quanto (sic) por la religiosidad de sus costumbres, el cariño y afecto de todos sus superiores sin que hubiese llegado a mi noticia la más leve queja de su conducta». Carta de 30 de marzo de 1840. AHN, Ultramar, Filipinas, 2201, Gracia y Justicia, expediente 12. Otro testimonio laudatorio en el mismo sentido lo proporciona el también profesor dominico Francisco de Sales, maestro en Filosofía, doctor en Teología y presidente del Colegio de San Juan de Letrán (carta de 18 de febrero de 1843). 
1833 nemine discrepante. Dos años más tarde aprobó en enero de 1835 las oposiciones a la cátedra de Filosofía del Real Colegio de San José. ${ }^{6}$

En los años siguientes Peláez asistió como pasante en las cátedras de la Universidad de Santo Tomás (1833-1836), recibiendo, tras los exámenes pertinentes, el grado de licenciado en Teología el 5 de diciembre de 1836. Desempeñó luego durante ocho años el cargo de preceptor de alumnos internos del colegio de Santo Tomás, a quienes impartió las asignaturas de Gramática Latina, Filosofía y Teología Moral.

Por nombramiento del rector y canciller de la Universidad realizó sustituciones en las cátedras de Filosofía y Teología, y regentó en ínterin durante casi un curso las dos asignaturas de Prima y Vísperas de Teología Escolástica de la facultad. Fue nombrado varias veces examinador para los grados mayores y menores de la facultad de Teología y, a petición del claustro en pleno, fue designado dos años conjuez de la Universidad. En 1837, tras haber recibido la tonsura, las 4 órdenes menores, el subdiaconado y el diaconado, Pedro Peláez fue ordenado sacerdote por el arzobispo de Manila José Seguí.7

Su formación universitaria culminó con la obtención del importante grado de doctor el día 10 de agosto de 1844.

Estos datos avalan la trayectoria de un eclesiástico competente y altamente preparado, como siempre lo reconocieron sus profesores. ${ }^{8}$ Peláez se mantuvo estrechamente unido a la Universidad de Santo Tomás el resto de su vida, pues entre 1836 y 1862 formó parte de su claustro, asistiendo regularmente a sus sesiones. ${ }^{9}$

\footnotetext{
${ }^{6}$ Fue nombrado para el cargo por superior decreto de 30 de enero de 1835 firmado por el capitán general Pascual Enrile: AHN, Ultramar, Filipinas, 2201, Gracia y Justicia, expediente 12. El cargo de catedrático de Filosofía del Real Colegio de San José fue dotado con 400 pesos anuales de salario provenientes del producto de la renta del colegio. En este mismo legajo, el antes citado P. Ayala, que acudió a las oposiciones para la cátedra de Filosofía de San José, refiere que Peláez «aventajó sobremanera a sus coopositores en la erudición y elocuencia de disertación y solidez de sus respuestas $\mathrm{y}$ argumentos».

${ }_{7}^{7}$ Peláez recibió la tonsura el 7 de diciembre de 1827 de mano del obispo de Nueva Segovia Francisco Albán, las 4 órdenes menores el 16 de junio de 1832, el subdiaconado el 13 de junio de 1835, el diaconado el 24 de septiembre de 1836 y el presbiterado el 28 de octubre de 1837; todas ellas por el arzobispo José Seguí. información extractada de las credenciales de Peláez en: AHN, Ultramar, Filipinas, 2201, Gracia y Justicia, expediente 12.

${ }^{8}$ Las fechas exactas de graduación, licenciatura y doctorado -que no ha referido ningún autor- han sido tomadas de diversas cartas credenciales de varias personalidades religiosas. Todas ellas están contenidas en el legajo anteriormente citado (AHN, Ultramar, Filipinas, 2201, Gracia y Justicia, expediente 12). En concreto, las aquí empleadas provienen de cartas credenciales escritas por dos arzobispos de Manila: José Seguí (10-III-1841) y José Aranguren (20-IX-1853).

${ }^{9}$ Agradezco esta noticia del archivo de la Universidad de Santo Tomás, totalmente inédita, al P. Villarroel.
} 
El currículo de Peláez parecía tenerle preparado una silla en el cabildo de la catedral de Manila, institución ansiada por los clérigos por la relativa comodidad que suponía su desempeño como por la decorosa subsistencia que garantizaba. Durante la época de dominio español no hubo cabildos en las diócesis sufragáneas; únicamente existió en la archidiócesis de Manila.

La primera ocasión para obtener un puesto en él se produjo en septiembre de 1837, cuando se presentó a las oposiciones de la canonjía magistral, vacante por ascenso de quien entonces lo ocupaba. En la terna que prosiguió a los exámenes Peláez fue presentado en segundo lugar, ganando la prebenda el licenciado Mariano García, hijo legítimo de indios principales, en quien se valoró sobre todo su antigüedad, según expresaría el asistente real P. Francisco Ayala, dominico, presente en el examen. ${ }^{10}$

La siguiente oportunidad vino dos años más tarde, cuando quedó vacante la misma canonjía por ascenso de García. Y esta vez sí, Peláez la ganó, recibiendo el nombramiento de modo interino en marzo de $1839,{ }^{11}$ y teniendo que dejar la cátedra que regentaba en el colegio de San José. ${ }^{12}$ De este modo comenzaba una larga y brillante carrera en el cabildo que duró hasta muerte.

Desde el principio Pedro Peláez desempeñó las funciones más variadas como las de mayordomo de fábrica, conjuez de causas o secretario. ${ }^{13}$

A éstas se añadieron muy pronto otras de mayor importancia, reflejo de la creciente estima que fue adquiriendo desde el principio por sus dotes e ilustración. En julio de 1839, el obispo de Nueva Cáceres Juan Antonio de Lillo, franciscano, le nombró juez subdelegado de la diócesis en Manila, continuando

${ }^{10}$ Así lo manifestaba el propio Peláez en carta sin fecha, pero posiblemente de 1840: «si bien se valuaron y calificaron mis ejercicios de escuela y púlpito a la par con los de mi coopositor, informando tan en abono de los míos el asistente real, que a su juicio a la antigüedad de García únicamente, y no a ventajas reportadas por este en el acto del concurso fue devida (sic) su precedencia en la terna». AHN, Ultramar, Filipinas, 2201, Gracia y Justicia, expediente 12.

${ }^{11}$ El 27 de febrero de 1839 el gobernador de Filipinas propuso a Peláez en primer lugar en la terna para desempeñar interinamente la canonjía magistral. El superior decreto de su nombramiento se firmó en Manila el 1 de marzo. AHN, Ultramar, Filipinas, 2201, Gracia y Justicia, expediente 12.

12 Según me especifica el P. Villarroel, existe en los archivos de la UST un documento en 1848 firmado por Peláez en el que solicita «por razón de sus compromisos» que se le dispense de la enseñanza en San José. Se puede concluir, en consecuencia, que de algún modo Peláez siguió unido a esta institución más allá de 1839, en que obtuvo interinamente la canonjía magistral.

13 Estos cargos menores fueron los de mayordomo de fábrica de la catedral y conjuez adjunto para las causas capitulares (7-I-1840; fue mayordomo hasta enero del año siguiente), y el de secretario capitular (19-VIII-1840; ocupó tal responsabilidad hasta junio de 1844). AHN, Ultramar, Filipinas, 2201, Gracia y Justicia, expediente 12. 
tales funciones durante el mando del obispo electo Tomás Ladrón de Guevara, del clero secular. ${ }^{14}$

Destacaba el P. Peláez por su capacidad intelectual y su gran oratoria, recibida con «aplauso general» en sus diversos sermones, de encargo, oficio o de tabla.

En 1841 salió a oposición la vacante de la canonjía magistral, ocupada interinamente desde marzo de hacía tres años por Peláez. Al acto, celebrado el día 6 de agosto, se presentaron junto a él, el criollo y miembro del cabildo Ignacio Ponce de León, ${ }^{15}$ y el español, recién llegado a las islas, licenciado Pedro Nolasco Elordi.

Como asistente real asistió el provincial de agustinos calzados fr. Juan $\mathrm{Zu}-$ gasti. Lo que en un principio parecía un examen normal se acabó convirtiendo en una prueba trufada de graves irregularidades a raíz de los cambios interesados que en ella se introdujeron, y, sobre todo, por el claro favoritismo mostrado por algunos examinadores y personas de relevancia hacia el opositor Elordi.

La primera alteración tuvo lugar el mismo día de su convocatoria, en la sacristía de la catedral, cuando el deán, el español Pedro Reales, intentó cambiar arbitrariamente el modo hasta entonces empleado de utilizar piques (señales) en el libro de las sentencias de Pedro Lombardo, que todos habían de emplear para una de las disertaciones. Reales trató de impedir el uso de cualquier señal en el libro aparentemente sin ninguna razón, pero con el propósito -como luego se vio- de favorecer descaradamente a Nolasco Elordi. El cambio originó una fuerte disputa entre el deán y Peláez, que protestó enérgicamente por la modificación introducida a última hora contra lo habitual en estas pruebas. A esta queja se sumó inmediatamente una recusación de Ponce de León, y el voto a favor del uso de piques en las oposiciones del canónigo Juan Rojas, comisionado por el cabildo para las puntuaciones. ${ }^{16}$

Chocó esto frontalmente con la pretensión del deán de imponer su criterio a toda costa, aduciendo para ello disponer de un voto doble y negando incluso el derecho del cabildo a intervenir. Con esta maniobra el señor Reales trataba de que la elección para la canonjía magistral fuera aprobada sin obstáculos por Elordi, que de este modo sería presentado en primer lugar en la terna al vicepatrono, quien a su vez, como amigo y paisano que era del opositor, no dudaría en designarle para la prebenda.

\footnotetext{
${ }^{14} \mathrm{El}$ nombramiento con el obispo Lillo se produjo el 23 de julio de 1839 y con Ladrón de Guevara el 7 de junio de 1843. AHN, Ultramar, Filipinas, 2201, Gracia y Justicia, expediente 12.

${ }^{15}$ El expediente personal de Ignacio Ponce de León puede consultarse en: AHN, Ultramar, filipinas, 2200/2, Gracia y Justicia, expediente 10 .

${ }^{16} \mathrm{El}$ expediente personal de Rojas, criollo, puede consultarse en: AHN, Ultramar, Filipinas, 2161, Gracia y Justicia.
} 
La maniobra del deán terminó por indisponerle con la mayor parte de los componentes del cabildo, ya hastiado por su carácter iracundo y los rápidos ascensos que anteriormente había promovido perjudicando a los miembros de más antigüiedad. ${ }^{17}$ La oposición se suspendió hasta nueva orden, mediando también una petición de anulación de lo obrado por el P. Peláez el día 18 de agosto.

Pasados los días se fueron conociendo más irregularidades, lo que incrementó las sospechas. Primero, Ignacio Ponce de León denunció que el asistente real, nombrado para la oposición, el agustino Juan Zugasti, no era siquiera profesor -como requería una real orden de 16 de junio de 1739-, y que además compartía amistad con el opositor Pedro Nolasco Elordi. ${ }^{18}$ Segundo, se supo que éste era hermano del fiscal de la Audiencia, Gaspar Elordi, y paisano y amigo del gobernador de Filipinas, Don Marcelino Oraa, todos de Navarra. Tercero y lo más grave, Ponce de León acusó a Pedro Nolasco Elordi de haber obtenido la condición de clérigo en Oñate, cuando era corte del pretendiente carlista, lo que presuntamente le inhabilitaba desde el punto de vista legal para participar en la oposición. ${ }^{19}$ Por todo ello el 21 de noviembre de 1841 el cabildo elevó una queja al regente del reino contra el deán y solicitando la provisión de la canonjía sin oposición en la persona de Peláez.

Mientras tanto, el anciano arzobispo de Manila, José Seguí, escandalizado, envió un oficio al cabildo lamentando los malos efectos que producían estas desavenencias y clamando por la unión y la fraternidad. ${ }^{20}$ El prelado, antes muy próximo al P. Peláez, pasó a responsabilizarle ahora de perturbar la paz del cabildo. ${ }^{21}$ Este cambio de actitud, según el siguiente gobernador, Don Francisco de Paula Alcalá, pudo deberse al hecho de que el arzobispo fue captado por el

17 De ello fue muy consciente el siguiente capitán general de Filipinas, Francisco de Paula, que en carta reservada remitida al secretario de Estado y del Despacho de Gracia y Justicia observó sobre el deán Pedro Reales: «Es una verdad que el Deán no cuenta en toda esta población [Manila] con una docena de amigos, porque su carácter lo tiene malquisto y aborrecido generalmente. Aún en el clero español (es decir el regular, porque en el secular hay pocos españoles) innumerables preferirían, en su caso, verse sujetos a algún eclesiástico del país, más bien que al deán». AHN, Ultramar, Filipinas, 2201, Gracia y Justicia, expediente 12. Manila, 6-X-1844. F. de Paula Alcalá. Carta reservada número 13. Para el gobernador el origen de todo el malestar en el cabildo era debido al deán.

18 Ibidem, el asesor de gobierno y el fiscal Elordi no admitieron la recusación por escrito de 20 de agosto de 1841 .

19 Ponce de León había conseguido esta información confidencial del secretario del cabildo, lo que molestó profundamente al deán, por tratarse de documentos reservados. De esta manera, y ante los temores del resto de miembros de la junta capitular, el denunciante acabó quedándose solo en su reclamación. Por su parte, Elordi presentaría sus documentos acreditativos, validados por el claustro de Oñate, el día 11 de junio de 1842.

${ }^{20} \mathrm{El}$ oficio del arzobispo está datado a día 4 de junio de 1842. A él contestó el cabildo procurando dar cumplimiento a sus deseos. AHN, Ultramar, Filipinas, 2201, Gracia y Justicia, expediente 12.

${ }^{21}$ Ibidem, el arzobispo manifestó en correspondencia privada sentirse defraudado por la actitud de Peláez temiendo que su actitud persistiese en caso de obtener en propiedad la canonjía. 
deán Pedro Reales, que vivía en su mismo palacio teniéndole casi como único consultor, y a ciertos tratos con el fiscal de la audiencia, Gaspar Elordi, hermano del opositor. ${ }^{22}$ De algún modo fue atraído por los navarros, incluido el mismo capitán general Oraa, que consideraba a Peláez como díscolo, litigioso y terco.

Con esta situación, no fue ningún problema para el superior gobierno de Manila desechar la recusación de Pedro Peláez y del cabildo para permitir la presencia del deán en las pruebas. ${ }^{23}$ Así las cosas, año y medio después, se convocaron otra vez oposiciones para la canonjía magistral.

Los ejercicios tuvieron lugar el día 6 de febrero de 1843, y parece ser que sin el uso de piques, como había promovido el deán y sus apoyos. Ésta vez, a la prueba se presentaron únicamente Elordi y Peláez. Ponce de León se excusó de acudir por enfermedad. Durante el examen el P. Peláez hizo gala de una apabullante superioridad con respecto a su rival, a juzgar por los profesores que asistieron al acto. Según consta le tocó realizar una exposición en latín sobre la licitud de las nupcias y el dogma de la resurrección de Jesucristo.

Su intervención levantó rendidos elogios de algunos de los asistentes: Antonio Díaz de Rebato, comisario de la Venerable Orden Tercera y profesor, aplaudió la presteza en las respuestas del opositor, añadiendo que «su coopositor Elordi en ningún concepto no puede ni con mucho igualársele». El catedrático de Teología en la Universidad de Santo Tomás, Domingo Treserra, dominico, habló de la notabilísima ventaja de Peláez y su «gran talento y distinguido mérito literario». Los también dominicos Francisco de Sales, maestro en Filosofía, doctor en Teología y presidente del colegio de San Juan de Letrán, y José Fuixá, catedrático de Filosofía en la Universidad, se recrearon en la solución «satisfactoria y hermosa» que dio a todas las cuestiones planteadas y en la «oratoria del púlpito». ${ }^{24}$

22 Ibidem, así expresaba Paula Alcalá esta sospecha: «Se cree que tiene un interés en favorecer a Elordi, parece ser que si el fiscal favorecía al arzobispo en sus cuestiones con el P. Bueno, Seguí lo haría con el hermano del fiscal en la canonjía. Es así como cambió el aprecio anteriormente manifestado de Seguí por Peláez, así como la elección de Elordi como secretario despidiendo anteriormente al que lo servía». Manila, 6-X-1844. F. de Paula Alcalá. Carta reservada número 13.

${ }^{23}$ Ibidem, Superior decreto, 26-XI-1842. Evidentemente, tanto el gobernador Oraa como el fiscal Elordi no dudaron en favorecer al señor Reales, sin duda la mejor garantía dentro del cabildo para la obtención de la canonjía vacante. Por su parte, el 1 de julio de ese año el cabildo había declarado suficientemente probada la recusación de Peláez.

${ }^{24}$ Ibidem, todos estos testimonios fueron recogidos ante notario por el propio Peláez. Las intervenciones tienen las siguientes fechas para el año 1843: Antonio Díaz de Rebato, el 6 de febrero; Domingo Treserra, el 9 de febrero; Francisco de Sales, el 18 de febrero; y José Fuixá, el 20 de febrero.

Hispania Sacra, LXIII

128, julio-diciembre 2011, 747-782, ISSN: 0018-215-X 
Llegada la votación por el cabildo, entonces con cinco presentes porque el resto estaba ausente o enfermo, cuatro votos resultaron favorables para Peláez y uno para Elordi. ${ }^{25}$ Evidentemente, este único voto provenía de su amigo el deán Reales.

Aunque Peláez tenía todas las de ganar la realidad fue otra. Terminados los exámenes, el capitán general, en calidad de vicepatrono, decidió entregar la canonjía a Elordi haciendo caso omiso a la terna en la que Peláez quedó el primero. ${ }^{26}$ Las razones de esta injusticia son las ya conocidas, y se resumen básicamente en el nepotismo del deán Reales y del gobernador Marcelino Oraá. 27

Fue lamentable la actuación del deán, pues con su carácter y manejos alteró innecesariamente la vida de un organismo que hasta entonces había funcionado razonablemente bien, y esto no sólo por la iniquidad perpetrada en la persona de Peláez - con quien el problema venía de tiempo atrás por cuestiones de honra- sino también por otros escándalos. El malestar creado fue grande. Durante un tiempo se aplaudieron con pasión los sermones de Peláez en la catedral, al paso que la concurrencia abandonaba el templo cuando hablaba Elordi. ${ }^{28}$

Nunca había habido en el cabildo enfrentamientos directos entre filipinos, criollos, mestizos o indios, y españoles. Más bien todo lo contrario, y los que hubo fueron entre los españoles. Pero desde entonces $-\mathrm{y}$ no sólo por responsabilidad de Reales, que además en breve marcharía a la Península- las cosas comenzaron a cambiar. El afán desmedido por introducir peninsulares en la junta catedralicia, aproximadamente desde mediados de los años cuarenta, suscitó conflictos insospechables, especialmente entre los mismos españoles.

Uno de ellos especialmente grave aconteció estos años entre el conocido Elordi y el provisor interino Antonio Torres Martínez, doctor en ambos derechos, que acababa de llegar de España con el propósito de gobernar la sede durante la convalecencia del arzobispo Seguí, entonces recuperándose fuera de la capital. Fue tal el enfrentamiento, que Torres, en acto calificado por el gobernador Narciso Clavería de «enajenación mental», llegó a encarcelar y poner inco-

25 Ibidem, el medio racionero interino de la catedral y pro secretario Cipriano García dio testimonio de los resultados el día 20 de febrero de 1843.

${ }^{26}$ Ibidem, Elordi tomó posesión oficial de la canonjía el 14 de noviembre de 1844.

27 Ibidem, el sucesor de Oraá en el mando, Don Francisco de Paula y Alcalá, criticó esta actitud del mandatario navarro en carta reservada contenida en este mismo legajo con el número 13 y fechada a 6 de octubre de 1844. Por cierto que en el desarrollo de la oposición se cometió una enésima irregularidad con el nombramiento como asistente real del agustino José Marcos. No era ningún secreto que éste había invitado a Elordi en varias ocasiones a la casa de campo de dichos religiosos durante los períodos vacacionales.

${ }^{28}$ Ibidem, esta noticia la proporciona Francisco de Paula Alcalá (Manila, 6-X-1844. Carta reservada número 13). 
municado al canónigo magistral Elordi, suscitando la dimisión del fiscal y miembros del cabildo. La cuestión concluyó con la destitución fulminante del provisor y su reemplazo por el bachiller en cánones Joaquín Arlegui..$^{29}$

El intento de potenciar el elemento español en el cabildo por motivos de carácter político, o de desconfianza hacia el elemento indígena en general, se esbozó lentamente con el gobernador Marcelino Oraa, ${ }^{30}$ que había hecho frente a la insurrección de Apolinario de la Cruz (1841) y a una intentona cuartelera de militares tayabenses, en enero de 1843, esta última casi coincidente con la oposición entre Peláez y Elordi. Se potenció durante el mandato de Clavería, y fue objetivo primordial en los años sesenta, tras la muerte de Peláez. No obstante, en esta paulatina separación de los clérigos del país, no se atisba inicialmente una especie de conciencia nacional, que tardará aún varios años en gestarse.

Volviendo a Peláez, lo que ha resultado de todos estos sucesos, aparte de la injusticia con él cometida, fue la valoración de su instrucción y gran prestigio, cualidades que le irían catapultando hacia el liderazgo del cabildo. Después de la malhadada oposición gestionó en la Península la obtención en propiedad de cualquier prebenda que vacase. ${ }^{31}$ Para ello contó con la ayuda de numerosos agentes o apoderados, entre ellos quizá el más destacado, por su persistencia en el tiempo, fue su sobrino Antonio Durán Peláez. Peláez fue un hombre de recursos, lo cual seguramente le vino dado por la importancia del cargo de su padre y el mantenimiento del contacto con sus familiares de España.

Su situación en el cabildo desde entonces no dejó de progresar. En los años siguientes ocupó una media ración (1846) y la canonjía magistral de modo interino, por muerte de su viejo rival Elordi (1847). Continuó ocupando otros cargos destacados como el de comisario de cruzada, examinador sinodal del arzobispado (1848-1863), penitenciario y otras comisiones a nombramiento del gobierno o encargo de la ciudad. De entre las responsabilidades desempeña-

${ }^{29}$ AHN, Ultramar, Filipinas, 2158/1, Gracia y Justicia. Manila, 4-VI-1845. Carta reservada número 34. N. Clavería al secretario de Estado de Despacho de Gracia y Justicia.

${ }^{30}$ El 15 de abril de 1844, conocida la cuestión habida entre Peláez y Elordi, la sección de Ultramar llegó incluso a sugerir la posibilidad de que todas o la mayor parte de las prebendas del cabildo se diesen sin oposición a españoles. Firman la petición Manuel García Gallardo y Ventura González Romero. AHN, Ultramar, Filipinas, 2201, Gracia y Justicia, expediente 12

${ }^{31}$ Algunas de las instancias de prebendas, contenidas en este legajo (AHN, Ultramar, Filipinas, 2201, Gracia y Justicia, expediente 12), fueron gestionadas por los siguientes agentes (entre paréntesis se indica el lugar, la fecha y lo solicitado): José Romero (Madrid, 20-IV-1842, canonjía magistral); Antonio Domínguez de Autillón (Cádiz, 26-XI-1843, canonjía magistral); Carlos Mendoza de Cisneros (Cádiz, 6-II-1844, solicitud de prebenda que vaque); y Antonio Durán Peláez (Jerez, 22-IX-1844, media ración u otra dignidad que vaque; Jerez, 29-IV-1845, medias raciones vacantes de la catedral; Cádiz, 8-I-1846, chantre u otra que vaque). Otros apoderados fueron Leoncio Mexía y Dávila y Miguel Plassard, que como veremos tuvieron otras implicaciones.

Hispania Sacra, LXIII

128, julio-diciembre 2011, 747-782, ISSN: 0018-215-X 
das, cabe citarse especialmente la de secretario capitular del arzobispo José Aranguren (1845-1850), con quien mantuvo estrecha amistad.32

Por entonces, Peláez ya era una figura de enorme ascendiente dentro y fuera del cabildo. A la muerte del arzobispo, fue vicario capitular en sede vacante y, más adelante, tesorero de la catedral. El ejercicio de estas funciones le brindó además un conocimiento de primer orden del funcionamiento de la iglesia en el archipiélago y de la situación del clero filipino, del que fue su más fiero y capacitado defensor.

\section{CAVITE, LA MANZANA DE LA DISCORDIA. LA REAL ORDEN DE 1849}

El 9 de marzo de 1849, mientras Peláez proseguía su ascendente carrera en el cabildo, se emitió una real orden por la que se mandaba la entrega de los curatos de Bacoor, Cavite Viejo (Kawit) y Silang a los agustinos recoletos, y los de Santa Cruz (Tanza), San Francisco de Malabon (General Trias), Naic e Indang a los dominicos. La medida sorprendió al arzobispo de Manila y al clero secular, formado en su inmensa mayoría por filipinos, porque sin razón aparente se les expropiaba una serie de administraciones que regentaban desde hacía bastante tiempo.

La disposición entroncaba con el espíritu de otros mandatos regios, especialmente con los del 8 de junio de 1826, cuando Fernando VII mandó la devolución de la parroquia de Malate a los agustinos y la restitución a las órdenes religiosas de todas las feligresías entregadas al clero secular desde $1768 .{ }^{33} \mathrm{La}$ ejecución de esta cédula tuvo un desarrollo desigual y jalonado de complicaciones y tensiones importantes en todas las diócesis del archipiélago. De algún modo, y con las excepciones propias de la iglesia hispano filipina -patronato, régimen de vicarios generales, ruptura en ocasiones de relaciones con Roma, baja instrucción del presbiterado diocesano-, la cédula de 1826 se quiso presentar como una medida justa, pues se legitimó en la devolución de las parro-

\footnotetext{
32 Peláez ocupó una media ración por ascenso de Arlegui (su nombramiento es del 29 de enero de 1844) y más adelante otra por muerte de Romualdo Alberto (superior decreto de 30 de mayo de 1846). Su nombramiento como canónigo magistral de modo interino está contenido en el superior decreto de Narciso Clavería de 11 de diciembre de 1847. Otros nombramientos son el de comisario de cruzada (23 de enero de 1846), el de secretario capitular del arzobispado (agosto de 1845 a mayo de 1850, en que renunció), y el de penitenciario (18 de octubre de 1854; toma de posesión el 25 de enero de 1855). Datos en: AHN, Ultramar, Filipinas, 2161, Gracia y Justicia, expediente 45; Idem, 2201, expediente 12; Idem, 2178, expediente 5; Idem, 2192, expediente 2; Idem, 2197, expediente 32; Idem, 2198, expediente 25; Idem, 2199, expediente 26.

${ }^{33}$ Roberto BLANCO ANDRÉs, «Hilarión Díez, provincial agustino y arzobispo de Manila en tiempos de crisis», Archivo Agustiniano, 88 (2004), 54-64.
} 
quias a sus fundadores. Pero con esto se colocaba al fraile en una situación de irregularidad canónica, pues su cometido original no era el de regentar un curato, tal y como ansiaba el real patronato.

Hasta la promulgación de la orden de marzo de 1849, las órdenes religiosas habían accedido a casi el $80 \%$ de las administraciones que se les adeudaba en función de la cédula de 1826. Este proceso culminó en 1870 con la entrega de San Simón, de la Pampanga, a los agustinos. ${ }^{34}$

Estos mandatos «regularizadores», o de entrega al clero regular, por oposición al secular, respondían a una mentalidad gestada, a paso lento pero constante, desde finales del siglo XVIII e inicios del XIX, especialmente tras la pérdida de las otras colonias. Se buscaba la conservación del territorio mediante la potenciación del elemento español en los principales puestos de decisión, en la administración, el ejército, y, por supuesto, en la titularidad de las parroquias.

En esta estrategia, patente en capitanes generales como Pedro Sarrio, Rafael María Aguilar, Juan Antonio Martínez, Rafael Enrile o Pedro Antonio Salazar, tuvo un papel de primer orden Narciso Clavería, que se esforzó enormemente en su aplicación práctica. Detrás de la real orden emitida por el expresado Clavería, capitán general y conde de Manila, se encontraba la mano del comisario procurador recoleto representante de la provincia de agustinos recoletos de San Nicolás de Tolentino en Madrid, Guillermo Agudo, y la actitud favorable de las autoridades españolas.

En marzo de 1848 el P. Agudo solicitó la entrega a su provincia de los curatos de Cavite, servidos por el clero filipino, cuando se produjese la vacante, para colocar a los definidores de su corporación y debido a las ventajas que reportaría el gobierno de los mismos por religiosos españoles. ${ }^{35}$

La petición de Agudo respondía también a una voluntad definida de la orden de agustinos recoletos de acceder a administraciones próximas a Manila, precisamente por el carácter periférico de su jurisdicción, pero sobre todo a las garantías recibidas en las altas estancias del Gobierno. De otro modo no se entendería la reclamación de una provincia entera. En concreto, tal y como explica el mismo Agudo en carta al provincial y definitorio, el Gobierno estaba planificando el aumento de los colegios misioneros con el propósito de incrementar el número de frailes para que se encargasen de los curatos de los clérigos seculares según fuesen vacando. ${ }^{36}$

\footnotetext{
${ }^{34}$ Datos en mi Tesis inédita titulada: Iglesia y Estado en Filipinas: Las órdenes religiosas y la cuestión de los curatos (1776-1872). Facultad de Filosofía y Letras, Universidad de Valladolid, 2004.

${ }^{35}$ AHN, Ultramar, Filipinas, 2164/1, Gracia y Justicia, expediente 2. Madrid, 27-III-1848, Guillermo Agudo, procurador recoleto, a la Reina.

36 Así decía la citada misiva: «Por el despacho anterior comuniqué a VVRR que el gobierno tiene un empeño formal en plantear los colegios más en grande que lo que están en el día, con el fin de que 
Por tanto, no es de extrañar que, sabido esto, Agudo hubiera recibido garantías del ministro de Gracia y Justicia y del Consejo Real para la obtención de esas feligresías para su provincia.

El arzobispo José Aranguren, solicitado su parecer, expresó inicialmente que la entrega de parroquias a recoletos -orden a la que pertenecía y de la que había sido provincial- e incluso hasta dominicos, podría ser en principio beneficiosa porque ambas tenían haciendas en Cavite. Los recoletos, en Imus y Bacoor y los dominicos, en Naic y Santa Cruz de Malabón. No obstante, debería desecharse taxativamente por el mal que originaría al clero secular de la diócesis. ${ }^{37}$

El prelado reconoció que sería un grave error despojar a los clérigos seculares de parroquias que les pertenecían desde hacía ochenta años en los que habían mejorado notablemente el estado moral y material de sus comunidades.

No era la primera vez que se oponía a este tipo de medidas defendiendo a su clero. Poco antes había evitado que los franciscanos se hicieran con la titularidad del pueblo de Quiapo. ${ }^{38}$ Además, dar pie a la solicitud de Agudo vaciaría el sentido de la política de su pontificado de fomentar el clero del país ${ }^{39} \mathrm{El}$ arzobispo era muy consciente de que disposiciones gubernativas, como la de 1826 y ésta que ahora se quería dictar, perturbarían el funcionamiento del clero diocesano en el que creía fervientemente.

Estas aprensiones no supusieron problema para Narciso Clavería a la hora de informar sobre la solicitud de Agudo. Como la medida potenciaba el elemento español, firmemente promovido por él desde su llegada, y dentro de las órdenes religiosas no había filipinos, debería aprobarse, aun violando los derechos más elementales del clero diocesano.

Existía además un precedente, la reciente aprobación en circunstancias idénticas de la entrega de la isla de Negros a la misma orden religiosa ${ }^{40}$ y una inne-

los curatos (como vayan vacando) que administran los clérigos se reasuman por los religiosos. Este proyecto, que según las explicaciones del señor ministro de Gracia y Justicia, y de los señores del Consejo Real a cuyas sesiones he asistido, se llevará a cabo indudablemente, me obliga a suspender la obra del Colegio por ahora hasta ver la resolución de este expediente». AM (Archivo de Marcilla, Navarra), Legajo 87, Número 1. Monteagudo, 10-IX-1847, Guillermo Agudo, procurador, al provincial y definitorio recoleto. El contexto de esta carta hay que relacionarlo con la elaboración de una serie de proyectos de misiones, de los que resultarían, entre otros, la puesta en marcha un nuevo noviciado franciscano.

${ }^{37}$ AHN, Ultramar, Filipinas, 2164/1, Gracia y Justicia, expediente 2. Manila, 15-XI-1848. J. Aranguren, a N. Clavería.

38 , John N., Schumacher, Revolutionary clergy. The Filipino Clergy and the nationalist movement. 1850-1903, Ateneo de Manila, University Press, 1981, 5.

39 APSR (Archivo de la Provincia del Santísimo Rosario, Ávila), Órdenes Religiosas, Tomo II, Documento número 13 C. Manila, 30-X-1848. J. Aranguren a N. Clavería.

${ }^{40}$ La solicitud para entregar la isla de Negros al clero regular había partido del obispo de Cebú Romualdo Jimeno, que había quedado impactado por el estado del clero de la diócesis tras la visita pasto- 
gable razón de carácter geopolítico. Cavite era una provincia estratégica en sus comunicaciones con Manila, por lo que siempre sería bien visto que su administración fuera ejercida por religiosos españoles, no por curas indígenas como ocurría hasta ahora.

Clavería desconfiaba de los sacerdotes indígenas. En sus visitas a las provincias, había criticado la indolencia y el abandono de sus templos, e incluso había llegado a proponer «apartarlos de esa carrera [eclesiástica] insensiblemente y en cuanto sea posible» por otros estudios más prácticos. Por todo ello, se mostró totalmente a favor de la demanda de Agudo, añadiendo además que la medida también podría extenderse a los dominicos, que ni siquiera habían realizado solicitud alguna. De este modo, la real orden de 9 de marzo de 1849 se hizo sobre la base de la instancia de Agudo pero con la redacción final de Clavería. ${ }^{41}$

\section{PELÁEZ Y GÓMEZ, LÍDERES DE LA PROTESTA CLERICAL}

Llegada la cédula a Manila comenzó a suscitar un profundo malestar entre el clero diocesano. Por la disposición, firmada por Isabel II, entregados los curatos señalados a recoletos y dominicos, el clero secular perdería 7 parroquias y retendría únicamente 4 (Cavite puerto -Cavite City-, Rosario, San Roque -actual distrito de Cavite City- y Marigondon -actual Maragondon-).

El sentido de la orden fue más ominoso porque era lisa y llanamente una expropiación en toda regla, a diferencia de la de 1826, que se había pretendido justificar en supuestos derechos de pretérita propiedad.

Esta injusticia no fue indiferente al clero secular, que comenzó a organizarse para protestar. Los hombres elegidos fueron el P. Pedro Peláez, miembro del cabildo y secretario del arzobispo, y el párroco de Bacoor y vicario foráneo de

ral. A pesar de que la isla había sido ofrecida inicialmente a dominicos y recoletos, Narciso Clavería se decidió por cederla íntegramente a los recoletos, que irían haciéndose cargo de sus parroquias según fuesen quedando vacantes (superior decreto de 20 de junio de 1848). En torno a esta preferencia por los recoletos algún autor ha señalado la amistad y proximidad entre el militar y los religiosos por vinculaciones de la familia del gobernador en la Península (Santiago SANZ DEL CARMEN, «El General Clavería y los PP. Recoletos», Boletín de la Provincia de San Nicolás de Tolentino, 1948, 136). Negros hasta el momento de su entrega había sido el único territorio de la extensa diócesis de Cebú que se había visto exento de la real orden de 1826. Puede consultarse además: Ángel MARTínEz CuESTA, «Evangelización de la isla de Negros, 1565-1660», Missionalia Hispánica, Tomo 30, número 90, Madrid, (1973); Modesto P. SA ONOY, A brief history of the Church in Negros Occidental, Bacolod City, printed by Bacolod Publishing House Ext., 1976.

${ }^{41}$ AHN, Ultramar, Filipinas, 2164/1, Gracia y Justicia, expediente 2, Madrid, 9-III-1849. Real orden de Isabel II a N. Clavería.

Hispania Sacra, LXIII

128, julio-diciembre 2011, 747-782, ISSN: 0018-215-X 
Cavite P. Mariano Gómez, sacerdote de virtud y de gran ascendencia entre los caviteños. ${ }^{42}$

No era la primera acción del clero secular contra una injusticia en la administración de los curatos ${ }^{43}$ pero ésta, a diferencia de las anteriores, se caracterizó por implicar a más curas, por estar liderada por sacerdotes nativos -un criollo y un mestizo-, por contar con mayores medios y al más alto nivel, incluida la presión en Madrid, y porque, como ha señalado el P. Schumacher en ella se atisban los primeros indicios de una conciencia nacional (awkening). Si bien, tal concienciación aludía a la constatación por un número creciente de presbíteros -mayormente nativos- de que la injusticia que se iba a cometer radicaba única y exclusivamente por su condición de filipinos.

Los primeros movimientos de inquietud entre el clero se registraron al poco de la llegada de la cédula. El epicentro de ese descontento se concentró en el pueblo caviteño de Santa Cruz de Malabón (Tanza), donde se produjeron reuniones en octubre de 1849. Según llegó a oídos del capitán general, durante las fiestas de esa localidad su párroco había proferido «expresiones subversivas» desde el púlpito de la iglesia. Los sucesos no sorprendieron para nada al arzobispo, que, lamentando ante la primera autoridad de las islas el sinsentido e injusticia de una disposición que privaba a los clérigos de buenas parroquias, justificó cualquier queja que tuviese lugar dentro de la legalidad.

De hecho, con casi total seguridad, monseñor Aranguren pudo estar informado de que Peláez y Gómez tenían en mente la elaboración de alguna exposición en defensa del honor de los clérigos y para «suplicar al mismo tiempo la reparación de los perjuicios que resultan al clero secular de privarle de los siete mejores curatos que posee en el arzobispado». ${ }^{44} \mathrm{Y}$ ello sin más lo podría saber de boca de su propio secretario Peláez, con quien tenía una gran afinidad.

El escrito fue redactado por Peláez y Gómez en nombre del clero caviteño. Se solicitaba a la Reina la derogación de la cédula, o bien la indemnización por las administraciones expropiadas, y se insistía en la lealtad del clero secular

\footnotetext{
42 Manuel Arsenio, Dictionary of Philippine biography, Quezon city, Filipiniana publications, 1955, I,195-199.

${ }^{43}$ Sobre protestas del clero secular contra reales órdenes lesivas de sus derechos puede consultarse: R. BLANCO, «Las órdenes religiosas y el litigio por el control de los curatos en Filipinas en el siglo XIX», en F. J. Antón Burgos y L. O. Ramos Alonso (ed.), Traspasando fronteras: el reto de Asia y el Pacífico, Asociación Española de Estudios del Pacífico, Centro de Estudios de Asia, Universidad de Valladolid, 2002, volumen I, 53-64; R. BLANCO, «El cabildo eclesiástico de Manila y la defensa de los derechos del clero secular de Filipinas», Philippiniana Sacra, vol XXXIX, number 115, JanuaryApril, University of Santo Tomás, Manila, Philippines, 2004, 19-143; R. BLANCO, «Hilarión Díez...», $35-46$

${ }^{44}$ AHN, Ultramar, Filipinas, 2211/1, Gracia y Justicia, expediente 66. Manila, 8-X-1849. J. Aranguren a N. Clavería.
} 
frente a las imputaciones proferidas gratuitamente por diversos sectores de la sociedad colonial. El arzobispo insistió al P. Gómez en la necesidad de obedecer a las disposiciones del Gobierno. El párroco de Bacoor, negó conocer o estar implicado en cualquier acto subversivo. Expresó su malestar más por las sospechas de traición que por la amputación de los curatos..$^{45}$

La protesta no fue presentada a las autoridades, pero acabó publicada el 8 de marzo de 1850 de forma anónima -se encabeza con «El Clero Filipino»- en el periódico madrileño El Clamor Público. ${ }^{46}$ El texto denunciaba que de 168 curatos existentes en la archidiócesis de Manila, sólo una quinta parte pertenecía al clero secular. A continuación, aparecieron impresas en el mismo periódico la réplica de Guillermo Agudo y varias contrarréplicas de Pedro Peláez.

En ellas, el procurador de los recoletos basó su argumentación en pretextos de legitimidad histórica, como el de reclamar los curatos de Cavite porque habían sido fundados por los jesuitas, mientas que el presbítero criollo utilizó un lenguaje más directo, cargado de erudición canónica y de denuncias a los excesos más comunes del clero regular. Desde entonces, Peláez no dejó de reprobar la ilegalidad del ejercicio del fraile como párroco, porque se trataba de una condición que sólo podía desempeñar, de acuerdo con el Concilio de Trento, cuando hubiese escasez de operarios, cosa que entonces no existía en Manila. ${ }^{47}$

Otra acción muy importante concertaron Peláez y Gómez: realizar una colecta para obtener fondos y sostener un agente en Madrid que trabajase por la derogación de la cédula de marzo de 1849.48 La idea seguramente partió del

45 J. N. Schumacher, Revolutionary clergy..., 6. La respuesta de Mariano Gómez era de 11 de octubre de 1849 .

${ }^{46}$ El texto fue reproducido por Pedro Peláez - con toda seguridad autor del mismo- en sus Documentos importantes para la cuestión pendiente sobre la provisión de Curatos en Filipinas, Madrid, Imprenta el Clamor público, 1863. Existe una copia del mismo en: AHN, Ultramar, Filipinas, 2214/2, Gracia y Justicia, expediente 30.

47 Todas las cartas están reproducidas en: P. PeLÁEZ, Documentos importantes..., 78-102. En ellas existe, además de la exposición, una carta de Guillermo Agudo fechada a 13 de mayo de 1850, y dos de Pedro Peláez de 3 y 12 de agosto del mismo año.

${ }^{48}$ Según explica Marcelino Gómez, sobrino del P. Gómez, en una memoria publicada en 1922, fue su tío quien primeramente inició las acciones de movilización destinadas a lograr la retirada de la cédula, uniéndose después voluntariamente «y sin insinuación de nadie» el P. Peláez, D. José Tuazon (Tuason) y Don Juan Lecaroz (Lecaros); estos dos últimos, se entiende, como agentes de aquellos. En los años cincuenta no podemos admitir la participación de Lecaros como agente del clero secular, por encontrarse entonces en Manila como conciliario del Banco Hispano-Filipino, igualmente que tampoco podemos negar la de Tuason, por desconocer si entonces estaba realmente implicado. Lo cierto es que es el sobrino de Gómez quien cita por primera vez -con nombres y apellidos- la intervención de estos dos personajes. De los dos, he podido confirmar con abundantes datos, encontrados fundamentalmente en la abundante correspondencia del procurador recoleto Guillermo Agudo en el archivo recoleto de Marcilla (Navarra), la participación de Lecaros como agente del clero secular en los años sesenta.

Hispania Sacra, LXIII

128, julio-diciembre 2011, 747-782, ISSN: 0018-215-X 
mismo Peláez, que ya sabía de la utilidad de emplear apoderados en la Península para obtener prebendas en el cabildo. Aunque no hay fuentes directas que citen personas desempeñando esa labor, no sería raro que su sobrino Antonio Durán Peláez llegase a estar implicado de algún modo en estas operaciones, como lo estuvo en los años sesenta, o incluso algún miembro del cabildo u otra persona de solvencia económica. En todo caso, es cierto que la única fuente contemporánea que he localizado alusiva al uso de posibles agentes -o lo que es lo mismo, la rica correspondencia de Guillermo Agudo- habla de un tal Romarte y otro Mexía como «corresponsales» de Peláez, lo cual encaja, pues al menos el segundo, que debe de ser Leoncio Mexía y Dávila, fue a ciencia cierta apoderado de Peláez en estos mismos años. ${ }^{49}$

En Filipinas, participaron en la colecta los párrocos de Cavite, los de Batangas, Manila y La Laguna. Todo el dinero recaudado se gestionó, según decían las instrucciones reservadas en su artículo tercero, «por los que en Manila dirigen este negocio». ${ }^{50}$ Se puede deducir, por tanto, que esas personas fueron, además del propio Peláez, alguno de los párrocos suscriptores de la capital.

Esta estrategia tiene un significado crucial, pues se trata de la primera acción, concertada a cierta escala, del clero filipino, dirigido por Mariano Gómez y Pedro Peláez, y fue tal su relieve que, en años posteriores, se usó para hacer frente a problemáticas de similar o mayor envergadura.

Por tanto, las palabras de Marcelino Gómez sobre el papel de su tío como pionero en la retirada de la cédula de 1849 -dejando a un lado el carácter hagiográfico que pudieran tener- no están del todo desencaminadas. Marcelino, GómEZ, 1922/1972, «P. Mariano Gómez», The Independent, 4 feb.15-22. Readings on Burgos-Gomes-Zamora, Part III: For colleges and universities, 99-119. Manila: BurgosGomez-Zamora Centennial Commision. Mimeographed. Agradezco el envío de este material al P. John N. Schumacher.

${ }^{49}$ El párrafo que trascribo a continuación es el único que, de los cientos de documentos leídos hasta ahora en el Archivo de Marcilla, proporciona alguna información sobre los agentes del clero secular en Madrid en 1850 (para los años sesenta contiene, por el contrario, abundantísima información). En él se explica que el citado Mexía -que entonces no conoce bien Agudo-, y otro tal Romarte, habían llevado un comunicado posiblemente de Peláez - del que tampoco sabe entonces gran cosa el mismo procurador recoleto-. Sin duda el comunicado que lleva Romarte y Mexía es el enviado desde Manila por Peláez y Gómez, que finalmente se publicó el 8 de marzo en El Clamor Público. Ello es fácilmente deducible porque Agudo escribe esta carta precisamente el 14 de mayo de 1850, es decir, un día después de que se publicase su respuesta a ese comunicado en el mismo periódico y con el propósito de dar cuenta a su provincial, P. Juan Félix de la Encarnación. «Por ésta [Dirección de Ultramar] atribuyen el comunicado a varias personas, pero según mis narices aunque no autor de los materiales, el que lo ha llebado (sic) a la redacción es Romarte: esto no pasa de ser una sospecha mía, sospecha que se estiende (sic) también a un tal Mejía o María [Leandro Mexía y Dávila], corresponsal de Pelaez, cuyo clerigo que creo es de ese cabildo no será extraño a los materiales». AM, Legajo 67, Número 6,18v. Madrid, 14-V-1850. G. Agudo a J. Félix de la Encarnación.

${ }^{50}$ Las instrucciones han sido reproducidas en: J. N. SCHUMACHER, Father José Burgos priest and nationalis, Manila, Published for the Knigts of Columbus. Ateneo University Press, 1972, 48-54. 
Aunque no se consiguió la anulación de la real orden del 9 de marzo de 1849 , tenemos noticia de que el clero intentó alargar la entrega de las parroquias a recoletos y dominicos por todos los medios, como la permuta de los curatos adeudados por presbíteros más jóvenes, para demorar su cesión. Esta actitud, planificada por Peláez y Gómez, suscitó en 1857, con motivo del retraso del traspaso de Naic, el malestar de los dominicos y las advertencias del capitán general Don Fernando de Norzagaray.

\section{VICARIO CAPITULAR DURANTE LA VACANTE ARZOBISPAL}

En los años siguientes, Pedro Peláez fue consolidando su posición en el cabildo y su ascendencia sobre sus compañeros. Era conocida su preparación, aplaudido su liderazgo y elogiada la oratoria que empleaba en sus sermones tanto en la catedral, como en Santa Isabel o en cualquier otro templo de la capital. En este tiempo había llegado incluso a colaborar en proyectos de reforma educativa planteados para Filipinas, o como visitador del hospital San Lázaro en extramuros. ${ }^{51}$

En el cabildo desempeñó varias medias raciones, el cargo de examinador sinodal del arzobispado, el de canónigo penitenciario y el de tesorero. ${ }^{52}$ Con estos antecedentes, cinco días después de la muerte del arzobispo José Aranguren, el 23 de abril de 1861 fue elegido vicario capitular y gobernador eclesiástico en sede vacante. Desde esta responsabilidad, Peláez intentó una estricta aplicación del derecho canónico y la ejecución de una serie de reformas que se venían gestando desde hacía tiempo.

Se puede especificar que este anhelo de reformas se produjo desde el interior y desde fuera, aunque con perspectivas distintas. Desde dentro, por una serie de medidas conducentes a mejorar el propio funcionamiento del patronato, tales como el perfeccionamiento de las condiciones del clero mediante la aprobación de la reforma de las dotaciones de los órganos eclesiales, el estudio de las asignaciones de los curatos dividiéndose en clases, promovidos por Don Narciso Clavería y Don Fernando de Norzagaray, o el arreglo misional de 1852, con el que se aprobó, entre otras medidas, la creación de un colegio misionero

\footnotetext{
${ }^{51}$ Gabriel F. FABELLA, Rizal the historian and other historical essays, Quezon City, The Philippine Historical Association, Inc, 1960, 132-135.

52 Datos provenientes de: AHN, Ultramar, Filipinas, 2171/1, Gracia y Justicia; 2192/1, expediente 27; 2197/2, expediente 32; 2198/2, expediente 25; 2199; Guía de Forasteros en Filipinas para el año de 1863, Manila, imprenta de Ramírez y Giraudier, 1863; Guía de Forasteros en Filipinas para el año de 1865. Manila, Establecimiento de los Amigos del país, 1865; C. Quirino, C., «A Checklist of Documents..., confunde este autor en la página 39, «gracioso» por gracia».
} 
franciscano en España, el restablecimiento de los jesuitas en Filipinas o el envío de los religiosos paúles a hacerse cargo de los seminarios conciliares.

Pero con todo, el aire más fresco vino de fuera, gracias al restablecimiento de las relaciones con Roma tras la firma del Concordato de 1851, superando los años anteriores de gran distanciamiento entre Madrid y con Roma, mayor aún para Manila.

El acuerdo supuso una mayor conexión entre la iglesia hispano-filipina y Roma, muy por encima de los rígidos márgenes del patronato. Figuras cruciales en este acercamiento fueron el dominico Francisco Gaínza, religioso virtuoso y gran canonista, y Lorenzo Barili, nuncio de Roma en Madrid, quien siempre buscó la unidad del episcopado insular («un corazón y una mente»).53

Ambos estudiaron en su correspondencia las condiciones de la iglesia hispano-filipina y manifestaron la necesidad de acabar con sus lacras más evidentes, como la práctica de que los obispos electos entrasen a gobernar antes de haber llegado las bulas, y la necesidad de la reforma del clero regular, y sobre todo, la urgencia de potenciar la jurisdicción diocesana, muy mermada por la fuerte autonomía de las corporaciones religiosas.

De algún modo, de esta relación epistolar y de la propia coyuntura eclesial de entonces, se infiere cierto estado de crisis o, si se prefiere, de necesidad de reforma, ante la persistencia de determinadas faltas o vicios.

Peláez también participó en este esfuerzo. Como vicario capitular conectó generosamente con Barili. ${ }^{54}$ Además, su excelente posicionamiento le proporcionó una perspectiva amplia del estado y necesidades de la iglesia y clero filipinos, así como un férreo convencimiento de la necesidad de aplicar reformas, o simplemente de hacer que se cumpliese escrupulosamente el ordenamiento canónico. Junto a esto, Peláez era a estas alturas un líder indiscutible dentro de la iglesia colonial, entre nativos y peninsulares, especialmente dentro del mismo cabildo. 55

Siendo vicario capitular, fundó junto a su amigo y profesor de la Universidad de Santo Tomás, Francisco Gaínza, el periódico El Católico Filipino, cuyo primer número apareció en el verano de $1861 .{ }^{56}$ En él publicó trabajos tan im-

\footnotetext{
${ }^{53}$ A. Uy, The State of the Church..., 203-204, 208, 257.

${ }_{54}$ Barili transmitió a Peláez la satisfacción del Santo Padre por su adhesión a la Santa Sede. APP [Archives of the Philippine Province], II-7-023, pp. 5-6. Madrid, 4-VIII-1961. L. Barili a P. Peláez. Agradezco al P. Schumacher el envío de este material.

${ }^{55}$ AHN, Ultramar, Filipinas, 2255/1, Gracia y Justicia. Manila, 22-VI-1863. G. Melitón al ministro de la Guerra y Ultramar.

56 Wenceslao Emilio Retana, Aparato bibliográfico de la historia general de Filipina, Madrid, Imprenta de la sucesora de M. Minuesa de los Ríos, 1906, III, $\mathrm{n}^{\circ}$ 4.475, 1.542-1.543. Gainza fue una persona muy próxima a Peláez, llegando a dedicarle varios de los muchos libros que escribió a lo largo de su vida.
} 
portantes como el Estadismo de Zúñiga. ${ }^{57}$ Su vida, no obstante, fue efímera. Al poco de su nacimiento la publicación sufrió algún encontronazo con el Diario de Manila, según parece por la crítica de Peláez a la permisividad del Gobierno ante la introducción de publicaciones progresistas, como el quincenal El Espanol de ambos mundos, o por las censuras de ciertos frailes intransigentes. Por todo ello, más adelante, se decidió la fusión de El Católico Filipino con La Oceanía Católica. ${ }^{58}$

Los trece meses que ejerció como gobernador eclesiástico prestó una atención pormenorizada y muy profesional a todas las funciones propias de un arzobispo. Dentro del cabildo exigió un mayor perfeccionamiento en su funcionamiento diario, reclamando mayor silencio, asistencia al coro y cumplimiento riguroso de sus funciones. Lamentó el estado lastimoso del seminario diocesano, intentando mejorar su situación y urgiendo el envío de los paúles, aprobado desde 1852. Mostró una preocupación creciente ante la poca moralidad de algunos miembros del clero secular y regular, exceptuando jesuitas y dominicos, mayor en las provincias que en la capital, y por ciertos militares y empleados de origen europeo. Aunque no creyó que la inmoralidad fuese generalizada en el seno de las órdenes religiosas, con excepción del caso clamoroso de la Orden de San Juan de Dios, opinó que debía de actuar contra ella la jurisdicción diocesana, desde su punto de vista más contundente y objetiva que la propia regular.

Intervino en todo lo que entraba en sus competencias. Peláez controló y estudió con detenimiento el funcionamiento del colegio de Tiples, los ramos particulares, los fondos de capellanías, las obras pías y los fondos parroquiales. Dictó medidas para la mejora de la administración temporal de las oficinas del arzobispado y sus empleados. Cuando Gregorio Melitón Martínez y Santa Cruz tomó posesión del arzobispado, recibió de manos de Peláez un informe detalladísimo y concienzudo..$^{59}$

\footnotetext{
${ }^{57}$ En concreto se publicó el prólogo de esta obra bajo el título de Viajes por los señores Peláez y Azaola, algo que desconocía Retana al realizar la reedición de Martínez de Zúñiga en 1893. Véase: Isacio RoDríGuEZ, Historia de la provincia agustiniana del Smo Nombre de Jesús de Filipinas, IV, Manila, 1968, 351-353.

58 «Parece ser- explica Retana- que a la sombra de las ideas religiosas, El Católico solía enseñar la oreja políticamente; quiero decir, que no todas sus ideas encajaban en el criterio genuinamente español». El periodismo filipino. Madrid, Imprenta de la viuda de M. Minuesa, 1895, 112. Gaínza se quejaba al nuncio de la situación culpando al gobernador por su indolencia. Barili agradeció a Peláez todos los números que le fue enviando en este tiempo y los puso a disposición del Papa. Por su parte el vicario capitular lamentó la fusión de El Católico Filipino con La Oceanía Católica, que en alguna ocasión lo achacó a la diversidad de «intereses e ideas» del clero. APP, II-7-023, 35-36, 37, 39-40.

${ }^{59}$ APP, II-7-024, pp. 2-21. Manila, 1862. P. Peláez a G. Melitón.
}

Hispania Sacra, LXIII

128, julio-diciembre 2011, 747-782, ISSN: 0018-215-X 


\section{PELÁEZ Y LA LUCHA POR LA IGUALDAD DEL CLERO FILIPINO}

Pero con todo, el momento más amargo que hubo de soportar Peláez y el presbiterado diocesano fue una medida contraria a los intereses del clero secular. El 10 de septiembre de 1861 una real cédula ordenaba indemnizar a los agustinos recoletos por las parroquias que habrían de ceder en Mindanao a los recién restaurados jesuitas, con los «curatos de la provincia de Cavite, u otros que hubiere servidos por el Clero indígena, al paso que vayan vacando». ${ }^{6}$

La medida había sido arrancada por el comisario Agudo del Señor Vida, amigo personal del recoleto y jefe del Negociado de Ultramar. Se había aprobado con el propósito de satisfacer las pérdidas que esta Orden iba a experimentar en Mindanao, en virtud del artículo 13 del decreto de 30 de julio de $1860 .{ }^{61}$

La real disposición no tenía para nada en cuenta los derechos de los clérigos seculares, a los que se perjudicaba sin ningún género de duda, por tener que desprenderse de gran cantidad de feligresías en toda la archidiócesis.

Llegada la real cédula a Manila, Peláez, siendo vicario capitular, pidió que se suspendiera temporalmente su aplicación al estar vacante la sede. Lo mismo pensaba Gaínza. ${ }^{62}$ Además, los primeros rumores en torno a su alcance, estaban ya suscitando fuertes temores entre los curas de Batangas, provincia en la que la clerecía secular conservaba importantes administraciones, salvadas de la ejecución de anteriores cédulas. ${ }^{63}$

A pesar de las objeciones, el asesor de gobierno Juan Pareja y Alba ordenó el cumplimiento de la real orden, desechando las consideraciones del vicario

60 AHN, Ultramar, Filipinas, 2211/1. Gracia y Justicia, expediente 66.

${ }^{61}$ En el envío de los jesuitas a Mindanao, con la condición inicial de ocupar toda la isla e inicialmente sin mediar indemnización alguna a los recoletos, fue determinante el parecer del obispo de Cebú, Romualdo Jimeno, a quien varios historiadores recoletos han culpado de los sucesos que acontecieron posteriormente. No obstante, detrás del envío de los jesuitas, también existía un indisimulado intento de ciertos cargos de la administración por anular cualquier influencia del clero indígena, como da cuenta de ello el tenor de ciertas comunicaciones reservadas del magistrado José Aguirre Miramón o el capitán general Fernando de Norzagaray con el Gobierno. A fin de cuentas se trataba del mismo espíritu que había inspirado las cédulas de 1826 y 1849. Por otra parte, la restauración de los jesuitas en Filipinas, coincidió con el nuevo propósito de Madrid por fortalecer el dominio en Visayas y Mindanao, plasmado en la creación de nuevos gobiernos político-militares (decretos de 30 de julio de 1860).

62 Isacio RoDRÍGUEZ y Jesús ÁlVAREZ, «Inquietud en la Iglesia de Filipinas: amovilidad e inamovilidad del clero regular», Archivo Agustiniano, 82 (1998), 238; APAF (Archivo de la Provincia de Agustinos de Filipinas) 839, 2-4. La respuesta de Peláez se firmó el 18 de diciembre de 1861.

${ }^{63}$ Esta noticia, tan poco conocida, la proporciona Peláez en una carta al provincial recoleto Juan Félix de la Encarnación, en la que le explica el disgusto del clero de Batangas por la cédula del 10 de septiembre de 1861. Guillermo Agudo y Celestino Mayordomo, Complemento de los documentos del folleto de 14 de noviembre de este año de 1863 sobre cuestiones de Curatos, Madrid, Imprenta de El Clamor Público, 1863. Documento número 25, 18. 
capitular. En consecuencia, el 6 de febrero de 1862 se comunicó oficialmente a recoletos y jesuitas que se dispusieran a dar los pasos necesarios para su aplicación. Al mismo tiempo, el gobernador Don José Lemery elevó a Madrid una serie de consultas para matizar su ejecución. El texto del 10 de septiembre de 1861 era muy poco preciso. Ni se definían las parroquias afectadas ni cómo proceder en el caso previsible de que los jesuitas -aún escasos en el país- tardasen en acceder a las administraciones que fuesen vacando en Mindanao. ${ }^{64}$ Cuando Agudo tuvo conocimiento de este paso del gobernador montó en cólera. ${ }^{65}$

Mientras tanto, el doctor Peláez no perdió ni un segundo. Sabedor de la importancia que tenía plantar batalla a una disposición tan onerosa comenzó a captar ánimos en el cabildo para redactar un escrito. Junto a él, estamparon su firma los también criollos Juan José Zulueta, Juan Rojas y Clemente Lizola, el primero murió unos meses más tarde; los dos últimos en el terremoto de 1863, junto con Peláez. Se entiende que el resto, o estaba ausente en la Península, o enfermo, o simplemente no se quiso involucrar por ahora.

El resultado fue la exposición del 14 de febrero, en donde se pedía la revocación de la controvertida cédula. De aplicarse en su totalidad, el clero secular, que entonces contaba con 34 parroquias de las 187 existente en el arzobispado, ${ }^{66}$ podría perder hasta 27 administraciones, el mismo número que entonces iban a ceder los recoletos a los jesuitas en Mindanao, con lo que finalmente sólo podría regentar escasísimas feligresías, por lo que se vería reducido básicamente a la labor de tareas de coadjutoría. Finalmente, al final de todo el proceso, fueron 21 las localidades cedidas en todo el arzobispado.

Lo más llamativo del texto del cabildo fue la sentida y emotiva defensa de la capacidad del clero. Con ello se trataba de dejar sin argumentos a los que siempre justificaban estas medidas expeditivas en su falta de preparación. ${ }^{67}$

Las semanas siguientes transcurrieron con bastante nerviosismo e inquietud en el cabildo. Peláez se sintió despechado, y estaba dispuesto a llevar su protesta hasta las últimas consecuencias. Si fuera preciso, mientras fuese vicario capitular, se negaría incluso a dar la institución canónica a los recoletos para los curatos de Cavite que les correspondiesen. El P. Gaínza intentó calmarle, pero sólo logró que rompiese un informe dirigido al Gobierno redactado en términos muy duros. En su lugar, el dominico escribió otro más templado.

${ }^{64}$ El informe de Pareja y Alba es de 18 de enero de 1862. I. RoDRíGUEZ y J. ÁlVAREZ, «Inquietud en la Iglesia de Filipinas», 241-242.

65 AM Legajo 88, Número 2. Madrid, 19-X-1862. G. Agudo a J. Félix de la Encarnación.

${ }^{66}$ Esta información, concretamente, fue expuesta en carta por Peláez al arzobispo de Manila, Gregorio Melitón Martínez, antes de su toma de posesión. APP, II-7-024, 2-21.

${ }^{67}$ Una copia de esta exposición en: APAF, 839, pp. 18-21. Entre los párrocos seculares que se citaban en el texto, como modelo de virtud, estaban los Padres Juan Zita, cura de Lubao, Hermenegildo Narciso, de Antipolo, y Modesto de Castro, de Naic.

Hispania Sacra, LXIII

128, julio-diciembre 2011, 747-782, ISSN: 0018-215-X 
Peláez sospechó que Agudo, cuya responsabilidad en la promulgación de la cédula de 1849 conocía, se encontrase también detrás de la nueva real orden, y no estaba dispuesto a que esta vez se saliera con la suya. ${ }^{68}$

En marzo el P. Peláez planificó una actuación contundente. Es la «polvareda espantosa» que refiere Montero y Vidal en su conocida Historia de Filipinas. ${ }^{69}$ El día 10 elaboró un extenso memorial desglosando todos los inconvenientes de la cédula de septiembre de 1861. En él, defendía el derecho canónico que asistía al clero secular en contra de caducos privilegios pontificios reclamados por las órdenes religiosas. Censuraba la pretensión de los frailes de perpetuarse en los curatos, olvidándose de las misiones. Lamentaba el «círculo vicioso» en que quedaban atrapados los clérigos, a quienes «no se educa con esmero porque su destino es ser coadjutor, y no se le dan mejores destinos porque no está esmeradamente educado». Y advertía de la gran animosidad que se estaba creando en el clero diocesano, muy consciente de esta injusticia. Los sacerdotes seculares quedarían sin posibilidades de promoción, por lo que se hacía necesario anular o modificar la real orden. ${ }^{70}$

A este escrito siguió otro firmado el 22 de marzo por la práctica totalidad de los miembros del cabildo, españoles, criollos, indios y mestizos, redundando en los mismos conceptos. El documento fue otra prueba más del ascendiente y liderazgo de Peláez..$^{71}$ Según Agudo, varios miembros de la Dirección de Ultramar le comentaron reservadamente, tras su lectura, que el texto era un auténtico «acto de insubordinación».72

${ }^{68}$ Es Francisco Gainza quien proporciona en carta al nuncio de 21 de febrero de 1862 algunas de estas noticias (Ángel MARTínEZ CUESTA, «El clero filipino. Estudios históricos y perspectivas futuras», Missionalia Hispánica, 40 (1983), 343). Seguramente Gaínza con el «informe» se estaba refiriendo al escrito de Peláez de 18 de diciembre de 1861. A mi entender, más que redactarlo íntegramente creo que el dominico realizaría algunas modificaciones del estilo, y que éstas no siempre fueron tenidas en cuenta por Peláez (y ello porque es el mismo Gaínza quien reconoce que «mi plan no ha salido bien»). Gaínza inicialmente estuvo muy al tanto de las intenciones de Peláez, y en más de una ocasión intentó orientarlo. Un ejemplo de ello es el Dictamen sobre la cuestión de curatos en Filipinas de 27 de marzo de 1862, escrito por el dominico a petición de Peláez. En torno a las sospechas de Peláez implicando a Agudo: G. Agudo y C. Mayordomo, Complemento de los documentos..., documento número 25, 1819. La reproducción de esta carta en un libro patrocinado por el mismo Agudo y el procurador agustino Celestino Mayordomo, no hacen más que confirmar las sospechas de Peláez.

${ }^{69}$ José, MonTERo y Vidal, Historia general de las Islas Filipinas, Madrid, 1895, III, 313.

70 Una copia de la exposición en: AHN, Ultramar, Filipinas, 2211/1, Gracia y Justicia, expediente 66.

${ }^{71}$ Estos son los firmantes y su origen, de acuerdo con una muy variada documentación existente en el Archivo Histórico Nacional. criollos: Pedro Peláez, Ignacio Ponce de León, Ramón Fernández, Juan Rojas, Juan José Zulueta, Clemente Lizola; españoles o peninsulares: Manuel Peralta, Agustín Puig, Francisco Gutiérrez Robles, Ramón Martínez Laviaron, y Calderón; mestizos: José Sabino Padilla y Feliciano Antonio (mestizo de sangley); otros filipinos sin identificar (puede tratarse de indios, aunque tampoco se puede descartar que sean criollos o mestizos): Félix Valenzuela (natural de Santa Cruz de Bay) y Cipriano García (natural de Zambales)

${ }^{72}$ AM Legajo 88, Número 2. Madrid, 3-VII-1862. G. Agudo a J. Félix de la Encarnación. 
La estrategia de Peláez entroncó de algún modo con cierta tradición contestataria del cabildo durante los períodos de sede vacante, en los que el Gobierno solía aprovechar para introducir modificaciones esperando no encontrar resistencia. Así había ocurrido, por ejemplo, durante el cambio de siglo o en los años veinte, cuando se rechazaron las pretensiones gubernamentales, en el primer caso con la férrea voluntad del cabildo por secularizar varios curatos pertenecientes a dominicos y recoletos, y en el segundo con la fiera postura mantenida por el provisor peninsular Pedro León de Rotaeche para mantener secularizado Malate frente a los agustinos y el gobernador. ${ }^{73}$

Aunque ambas situaciones se saldaron con disposiciones proclives a las corporaciones monásticas, las dos fueron los mejores antecedentes de la acción meditada por Peláez. Las conocía más o menos, pero la acción del vicario capitular contenía algunas diferencias y una proyección muy distinta, al menos en cuanto a sus ulteriores implicaciones de carácter puramente nacional, así como en las notables influencias posteriores, tal y como ha señalado acertadamente el P. Schumacher en la herencia ideológica del P. Burgos o en la generación de $L a$ Propaganda.

En 1849, como en 1861, las Reales Órdenes en materia de curatos fueron concienciando paulatinamente al clero secular de que la injusticia se cometió por su condición exclusiva de filipinos indios, mestizos o criollos. Sabemos que apenas había españoles entre ese clero, a pesar de los esfuerzos de Peláez. Igualmente, esas disposiciones fueron contra el clero archidiocesano, más instruido que el existente en el primer cuarto de la centuria, y más movilizado, como ya se había podido ver diez años atrás en la campaña orquestada por Peláez y Gómez. Se formó en los colegios de la capital, de mayores cualidades que los seminarios, entonces en un estado lamentable.

Peláez fue además el primer líder puramente filipino en defender cuestiones eclesiásticas en un puesto de gran relevancia. Su alta preparación, sus modos de obrar, su solidez argumentativa, la lógica racial y su orgullo innato fueron abriendo de algún modo la mente a una especie de sentir nacional filipino», a una mentalidad, inicialmente forjada entre el clero, de que los nacidos en el archipiélago, cuándo recibían una instrucción similar a los peninsulares, eran como mínimo iguales a ellos.

Llegados a este punto, el asesor Pareja y Alba volvió a rechazar las alegaciones de Peláez y del cabildo. En su propósito abundó en descalificaciones racistas y en la superioridad del europeo en una línea muy similar a la filosofía que ampararía la carrera imperialista de la conferencia de Berlín de 1885.74

${ }^{73}$ R. BLANCO ANDRÉS, «El cabildo eclesiástico de Manila...».

${ }^{74}$ AM, Cavite, Legajo 48, Número 1. Manila, 27-III-1862. J. Pareja y Alba a J. Lemery.

Hispania Sacra, LXIII

128, julio-diciembre 2011, 747-782, ISSN: 0018-215-X 
Pareja parecía obviar, no sólo las reglas más elementales del derecho canónico, sino también que la protesta venía avalada por la firma de varios peninsulares. El gobernador Lemery se asustó al conocer los acontecimientos. Desautorizó, como hizo su antecesor, al cabildo por «sostener esa igualdad insostenible que se pretende entre el clero secular y el regular». Temeroso del cariz de los acontecimientos y de que el cabildo se opusiese a ejecutar la cédula, prefirió quitarse el problema de encima optando el 21 de mayo por remitir todo el expediente a Madrid para su resolución.75

Desde Madrid el procurador recoleto Guillermo Agudo, que por sus influencias seguía atentamente el curso de los acontecimientos, prometió a su provincial ser implacable con Peláez y el resto de canónigos de la catedral: «¿acaso porque haya paz si nos quitan la capa les hemos de dar también la camisa?».76

En éstas llegó por fin a Manila el arzobispo Gregorio Melitón Martínez y Santa Cruz, poniendo fin a la vacante el día 27 de mayo de 1862. Cesó entonces el P. Peláez como gobernador eclesiástico. Según reconoció años más tarde, en su llegada, el nuevo arzobispo encontró muy soliviantado al clero indígena y «por todas las partes se le urgía a que pidiese la revocación de la enunciada real orden de diez de Setiembre». ${ }^{77} \mathrm{La}$ voz más autorizada obviamente fue la de Peláez, quien le puso al día del carácter de la cédula.

Confiaba en que el prelado, por su condición de secular, tendría una mayor predisposición hacia las necesidades del clero de la archidiócesis. Como en tantas otras cosas, no anduvo desencaminado. Puede afirmarse que Pedro Peláez atrajo a su campo al arzobispo en todas sus tesis, no sólo en lo relativo a la injusticia de la cédula, sino también en cuestiones relativas a la jurisdicción diocesana, en lo que también influyó el dominico Gaínza. Y así, por de pronto, el arzobispo se opuso a la institución canónica del recoleto que se había presentado para cubrir el curato de Antipolo (provincia de Morong, hoy Rizal), primero en vacar en la archidiócesis tras haber entregado en Mindanao el pueblo de Mainit. Fueron tales las razones argüidas, que hasta el nuevo gobernador, Rafael Echagüe, sabiendo de las consultas planteadas por Lemery y juzgando incluso temeraria la actitud de su predecesor, decidió suspender por decreto de 9 de agosto todo lo obrado hasta que viniese la disposición pertinente de Madrid. ${ }^{78}$

El éxito de Peláez y del arzobispo fue efímero. Tan sólo una semana después llegó una real orden aclaratoria, con fecha de 20 de junio, en respuesta a las du-

75 AHN, Ultramar, Filipinas, 2211/1, Gracia y Justicia, expediente 66. Carta reservada no 579. Manila, 21-V-1862. J. Lemery al ministro de la Guerra y Ultramar.

${ }^{76}$ AM Legajo 88, Número 2. Madrid, 3-V-1862. G. Agudo a J. Félix de la Encarnación.

${ }^{77}$ AHN, Ultramar, Filipinas, 2255/2, Gracia y Justicia, Expediente 6. Manila, 31-XII-1870. G. Melitón Martínez al regente. Una reproducción en: J. ScHUMACHER, Father Jose Burgos..., 194-218.

78 AHN, Ultramar, Filipinas, 2211/1. Gracia y Justicia, expediente 66. Manila, 9-VIII-1862. 
das representadas por Lemery sobre la aplicación de la cédula de 10 de septiembre de 1861. Los curatos comprendidos en la indemnización a los recoletos serían los del arzobispado. Cuando se hubiera procedido a la vacante y la entrega de una parroquia de esta Orden a la Compañía de Jesús se habría de indemnizar a aquellos con otra feligresía de la archidiócesis, servida por el clero indígena y que vacase en el modo estipulado.

Detrás de esta resolución estaban la voluntad inamovible del Gobierno y, de algún modo, ciertas gestiones del procurador recoleto. El temeroso provincial de agustinos descalzos felicitó efusivamente a Agudo por sus gestiones: «yo opino que esa real orden de 20 de junio es un triunfo para ti sobre los clérigos». ${ }^{79} \mathrm{Al}$ conocerla, el clero secular se crispó aún más si cabe. Peláez ni siquiera tuvo en cuenta las indicaciones de Gaínza de que desistiese en su empeño; es más, comenzó a actuar con mayor independencia respecto al dominico. 80

\section{ANTIPOLO, «LA PERLA DE LOS CURATOS»}

Antipolo estaba destinado a convertirse en el principal punto de conflicto entre el clero de la diócesis y la provincia de agustinos recoletos de San Nicolás de Tolentino por la aplicación de la cédula de 1861.

Tras las últimas explicaciones de la Dirección de Ultramar parecía claro que el traspaso de curatos a los recoletos se haría sin problemas. Pero no fue así. Aunque el arzobispo acató el contenido de las Reales Órdenes, se opuso a la cesión de Antipolo por no estar comprendido en los casos en ellas contemplado, tal y como supo ver sibilinamente junto a Peláez. Éste, por su parte, aunque satisfecho por la firmeza del prelado decidió mover hilos en Madrid. De ello ya tenía experiencia de los años en que había intentado anular la real orden de 1849.

Como entonces, usó agentes en la capital española. Indicios indirectos y muy solventes hablan de más de una persona implicada. Entre ellas se encontrarían Juan Francisco Lecaros, filipino de ascendencia mexicana y de forma-

${ }^{79}$ AM, Legajo 88, Número 2. Madrid, 19-X-1862. J. Félix de la Encarnación a G. Agudo.

${ }^{80}$ A. Uy, The State of the Church in the Philippines..., 239. cifr. Carta de Gaínza a Barili con fecha de 20 de agosto de 1862. Igualmente, el 8 de octubre llegó a Manila la respuesta de la Dirección de Ultramar firmada en Madrid el 31 de julio en torno a la petición del cabildo eclesiástico de suspensión o modificación de la real orden de 10 de septiembre de 1861. En ella se ordenaba estar en todo a la expresada disposición y a su aclaratoria de 20 de junio. G. AGUdo y C. MAYORDOMO, Importantísima cuestión que puede afectar gravemente a la existencia de las islas Filipinas, Madrid, Imprenta de El Clamor Público, 1863, documento número 7, 34 .

Hispania Sacra, LXIII

128, julio-diciembre 2011, 747-782, ISSN: 0018-215-X 
ción jurista, el sobrino de Peláez, Antonio Durán Peláez y algunos miembros españoles del cabildo que por entonces se encontraban en Madrid.

En principio, parece que el arzobispo no tenía constancia directa de estas acciones. Quizá Peláez prefirió mantener en este punto mayor autonomía. Es de presumir que si Gregorio Melitón hubiese estado al tanto de ellas y les hubiese dado el visto bueno, habría podido optar por contactar con su influyente tío, el conde de Cerrajería. Gaínza, en cualquier caso, temía que Peláez implicase en exceso al metropolitano: «como todo el mundo lo mira como la personificación de los hijos del país, y aun se le llama insurgente a boca llena, temo comprometa al Arzobispo».81

El temor de los recoletos a nuevas demoras les hizo emplearse a fondo. Guillermo Agudo abrió la agenda de sus contactos en Madrid. Tras quince años como comisario procurador, caso único de duración entre los frailes que en ese siglo ejercieron el cargo, sabía perfectamente a quién tenía que dirigirse. El objetivo era presionar en la Dirección de Ultramar para obtener garantías de la propiedad de la parroquia.

Comenzó llamando a la puerta del anterior gobernador de Filipinas, Don José de Lemery, recién llegado del archipiélago, que tras un encuentro con el religioso declinó inmiscuirse en la cuestión por afectar a su sustituto en el cargo. Prosiguió con los hermanos Estrada, Manuel y Luis, el primero amigo de los recoletos y el segundo con cierta influencia política y con alguna vinculación con la colonia. Agudo consiguió de ambos una denuncia de las acciones del arzobispo ante la Dirección de Ultramar, arrancada en el caso de Luis Estrada mediante mentiras y engaños, tal y como reconoce con jactancia en su correspondencia con el provincial en Manila.

Se entrevistó al más alto nivel con personalidades que ocupaban cargos importantes. Lo hizo con Don Tomás Hevia Campomanes, miembro del Consejo de Estado, y con Don Faustino San Pedro, del ministerio de la Gobernación, para cerrar las peticiones del canónigo español Ramón Martínez Laviaron, que se había dirigido a estas personas -a instancias de Peláez- posiblemente para interceder por el clero en la cuestión del curato de Antipolo. ${ }^{82}$

${ }^{81}$ A. Uy, The State of the Church in the Philippines..., 100. Carta de 5 de agosto de 1862. Gaínza explicaba también en esta misma carta al nuncio que el arzobispo estaba ante el dilema de usar los servicios de Peláez o librarse de él, pues, si hemos de creer al remitente, éste fue consultado por Melitón Martínez sobre la conveniencia de nombrar al presbítero como «obispo de Cuba, Puerto Rico, Santo Domingo, etc, para alejarlo de aquí».

${ }^{82}$ Los contactos de Agudo con los Estrada comenzaron como mínimo en septiembre de 1862. La reunión con Lemery fue a principios de noviembre. Y la intercesión ante el Consejo de Estado y el Ministerio de la Gobernación entre noviembre y diciembre. AM Legajo 88, Número 2. Madrid, 3-XI1862; 19-XI-1862, 3-XII-1862.; todas están escritas por G Agudo a J. Félix de la Encarnación. 
A pesar de que la acción se estaba planteando en Madrid, la primera resolución del expediente se produjo en la ciudad del Pasig. El 22 de diciembre de 1862 la Real Audiencia de Manila, previo el voto consultivo de los señores Triviño, Vela y Heras, determinó que el provincial recoleto presentase la terna para el curato de Antipolo en concepto de indemnización por la entrega -se decía ahora- del pueblo de Santa Isabela de Basilan (archipiélago de Joló). ${ }^{83}$

No es baladí que la parroquia de Antipolo estuviese concentrando tanto encono y conflicto. A la ilegalidad denunciada por Peláez, los clérigos y el arzobispo, se sumaba la condición de la feligresía. Antipolo era uno de los curatos más pingües de Filipinas, la «perla de los curatos» en palabras del arzobispo; su condición de santuario de la Virgen de la Paz y del Buen Camino generaba abundantísimas obvenciones, limosnas e ingresos a cualquier ministro que lo regentase. «Si matan a todos los clérigos Indios, y no Indios, no lo sentirían tanto como si se les quita a Antipolo, y Santa Cruz», había reconocido alguien en la Dirección de Ultramar. ${ }^{84}$

Aún con los dictámenes de la Audiencia en contra, Pedro Peláez decidió seguir adelante contra viento y marea. A principios de enero el cura que entonces interinaba en Antipolo, y que en breve tiempo debía abandonarlo, el criollo Francisco Campmas, protestó alegando que su parroquia no podía entenderse comprendida en cualquiera de las cédulas. El texto estaba inspirado, sino redactado, por el mismo Peláez.

Antipolo, se afirmaba, no podía ser entregado a los agustinos recoletos por la vacante de Santa Isabela de Basilan porque las disposiciones reales decían que la indemnización a estos religiosos sólo tendría lugar, una vez que los jesuitas ocupasen efectivamente la administración dejada por los recoletos en Mindanao, y después con el curato que vacase a continuación en la archidiócesis, no con el que hubiese vacado anteriormente; circunstancia en la que se encontraba Antipolo. 85

A pesar de la lógica del razonamiento, el gobernador y vicepatrono Rafael Echagüe desatendió la queja así como el recurso de apelación que Campmas interpuso de inmediato. « ¿aya, están locos!» exclamó Agudo al saber de la terquedad de Peláez y los clérigos. ${ }^{86}$ Gregorio Melitón no tuvo más remedio que

${ }^{83}$ AHN, Ultramar, Filipinas, 2211/1, Gracia y Justicia, expediente. 66. Manila, 31-XII-1862. R. Echagüe a G. Melitón.

${ }^{84}$ AM Legajo 88, Número 2. Madrid, 3-XII-1862. G. Agudo a J. Félix de la Encarnación.

${ }^{85}$ Antipolo había vacado en enero de 1862 y Santa Isabela de Basilán se había provisto en un jesuita en septiembre. Está claro entonces que Antipolo -seguramente por descuido en la redacción de la Real orden- no estaba comprendido en la indemnización. La protesta de Campmas puede verse en: P. PeláEZ, Documentos importantes..., 118.

${ }^{86}$ El provincial recoleto J. Félix de la Encarnación creía que Peláez estaba pensando incluso en la posibilidad de llevar la demanda hasta el nuncio monseñor Antonelli, y aún al Papa. AM, Legajo 88, Número 3. Madrid, 19-III-1863. G. Agudo a J. Félix de la Encarnación. 
ceder e instituir canónicamente el 26 de enero a un religioso recoleto en Antipolo, pero para manifestar su disgusto lo hizo con la fórmula «bajo protesta».87

No se sabe que, muy confidencialmente, el arzobispo continuó trabajando con gran tesón para que Antipolo retornase al clero secular. El 3 de febrero de 1863 insistió ante el gobernador Echagüe en los mismos razonamientos ya esgrimidos por Peláez/Campmas, y el 21 de agosto, ya muerto Peláez, se dirigió a través de su tío, el conde de Cerrajería, al político liberal don Manuel Aguirre de Tejada, ministro de Ultramar en los años ochenta, para que intercediese en el asunto de Antipolo. ${ }^{88}$

En el año y medio siguiente, mediando en el intervalo fuertes polémicas en la prensa contra el mismo prelado, el pleito se dirimió en los organismos oficiales de Madrid. Aunque comenzó con buen pie y con informes favorables al clero secular, Guillermo Agudo captó, mediante gratificaciones o sobornos de hasta 3.000 pesos, con un anticipo de 300, a dos miembros del Consejo de Estado. Con ello logró una real orden el 19 de mayo de 1864 sobre la propiedad de Antipolo, así como la elaboración de unas bases muy ventajosas para la adquisición de los curatos adeudados en el arzobispado. ${ }^{89}$

\section{EL «ORÁCULO» DEL CLERO}

La protesta por el asunto de Antipolo se mezcló con las propuestas de reforma de la iglesia filipina lanzadas por varios obispos en febrero de 1863. Peláez, como amigo de Gainza y como implicado profundamente en las acciones del arzobispo, estuvo al tanto de todos los movimientos de la jerarquía diocesana, que alentó con su pensamiento y acción. Ese mes coincidieron en la capital tres obispos de decidida voluntad reformista: el arzobispo de Manila, único del clero secular en todo el siglo XIX, el obispo electo de Nueva Cáceres, Francisco Gaínza, y el obispo de Cebú, Romualdo Jimeno, que había acudido para la consagración de su compañero de Orden, que tuvo lugar el día 22.

Se trataba de una ocasión única. En varias reuniones, los prelados hablaron de la necesidad de empezar a poner en marcha las reformas de las que tanto ha-

\footnotetext{
${ }^{87}$ En la Dirección de Ultramar también creían que el arzobispo se encontraba bajo la influencia de Peláez. Así lo expresó en una ocasión Don Miguel Sanz, oficial de dicho organismo, al procurador recoleto: «es un pobre hombre y le harán firmar los mayores acuerdos». AM Legajo 88, Número 3, Madrid, 19-IV-1863. G. Agudo a J. Félix de la Encarnación.

${ }_{88}$ AHN, Ultramar, Filipinas, 2204/2, Gracia y Justicia, expediente 64. Manila, 21-VIII-1863. G. Melitón a Manuel Aguirre de Tejada. Carta confidencial del arzobispo sobre el curato de Antipolo

${ }^{89}$ Una de las cartas que informa de estas cuestiones está en AM Legajo, 88, Número 3, s/n, Carta reservada. Madrid, 3-XI-1863. G. Agudo a J. Félix de la Encarnación. Conviene destacar que este documento se ha conservado milagrosamente, pues en su contenido el procurador recoleto pedía expresamente a su provincial que lo destruyese.
} 
bían hablado por correspondencia desde hacía tiempo. Todos eran conscientes de que la iglesia insular necesitaba cambios. Gaínza los había expuesto en sus cartas con el nuncio Barili y en sus escritos (Reflexiones sobre la reforma de los Regulares de Ultramar). Jimeno los manifestó en sus desavenencias con los agustinos de Panay; y Gregorio Melitón estaba en Filipinas, al fin y al cabo, como garantía de algunas autoridades preocupadas de la Dirección de Ultramar -como su director, el señor Ulloa- para mejorar las costumbres del clero regular. No debe olvidarse que el mismo Peláez también las había pregonado en El Católico Filipino, durante su gobierno de la sede vacante, en sus encuentros con Gaínza y en sus misivas al nuncio. Había llegado por tanto el tiempo de intentar aplicarlas.

Aprovechando esta excelente coyuntura, el 25 de febrero los tres obispos firmaron una exposición -redactada por Gaínza- en la que después de lamentar el estado de indisciplina y decadencia en que habían caído las corporaciones monásticas, proponían la anulación de la real orden de 1795 sobre inamovilidad del clero y el establecimiento de la amovilidad ad nutum (a la menor seña) de los párrocos regulares en el punto en que había sido establecido por Benedicto XIV, esto es, que los frailes que ejercían la cura de almas pudiesen ser removidos por los superiores provinciales o por los obispos - primando la potestad de estos sobre la de aquellos en caso de colisión - sin necesidad de instruir una causa canónica de la que resultara la remoción..$^{90}$

La petición de movilidad suponía en realidad un enésimo intento por fortalecer la mermada jurisdicción diocesana en la iglesia de Filipinas. Los prelados creían que la inamovilidad del clero regular -conferida por la institución canónica- era un motivo serio de desobediencia y relajación. Con este sistema, según señalaba la prelatura insular, era muy difícil encausar a un párroco díscolo sin un fuerte escándalo: el cura canónicamente instituido podía falsear el resultado de las indagaciones contra él por su influjo en la comunidad -de hecho muchas acusaciones se retiraban por temor-, y podía a la vez dar lugar a un ruidoso conflicto al poder oponerse a su superior.

Del mismo modo, los obispos también plantearon otras reformas de importancia en torno a la duración de provincialatos, la dotación de provisores y fiscales, el respeto por los alcaldes mayores de los privilegios eclesiásticos, la solicitud de división de las diócesis, el incremento del clero secular o la división de las parroquias de mayores dimensiones, entre otras.

A principios de marzo los tres obispos expusieron a los superiores regulares su plan sobre la amovilidad y la reinstauración de la ley del claustro (prohibición de la entrada de mujeres en los conventos/casas parroquiales). Aunque ini-

${ }^{90}$ Una copia en: AHN, Ultramar, Filipinas, 2205, Gracia y Justicia, expediente 41. 
cialmente mostraron cierta proclividad, con excepción de algunas frases, modificadas por el arzobispo en un nuevo borrador, finalmente franciscanos, agustinos y recoletos optaron por desentenderse. Los dominicos dieron su visto bueno y los jesuitas evitaron pronunciarse por tener ya lo que se estaba pidiendo. ${ }^{91}$

Resultó especialmente desafortunada la presencia de varias frases inconvenientes en el texto de la exposición, que fueron explotadas hábilmente por los frailes detractores para rechazarlas en su totalidad. La más evidente era la que hacía caer el peso del estado de la inmoralidad sobre el conjunto del clero regular, sin ni siquiera citar al clero secular. Aunque ésta fue la piedra angular de su oposición, detrás de la negativa a firmar se encontraba sin duda el temor a que si prosperaba la petición se podría poner en marcha la temida secularización de sus parroquias.

Con todo, la exposición, reelaborada por tercera vez, se entregó formalmente al superior gobierno para su pase al Consejo de Administración, previa a su remisión a los organismos peninsulares de Ultramar.

En los meses siguientes la cuestión se hizo vox populi en una Manila cada vez más inquieta. ${ }^{92}$ Controversias interminables, escritos de todos los colores, réplicas, contrarréplicas, libelos anónimos, reuniones tumultuosas y movimientos en la sombra fueron la dinámica entre marzo y junio. Unos creían llegado el momento del cambio, de la reforma; otros de afianzar el status quo. Para todos, religiosos y presbíteros, se estaba viviendo un momento crucial en la defensa de sus derechos.

Previo al informe del Consejo de Administración, frailes y clérigos seculares intentaron predisponer el ánimo de los consejeros. El primero en hacerlo fue el provincial de recoletos, Juan Félix de la Encarnación, que en su escrito titulado Contestación razonada a la exposición de los señores obispos hizo una apasionada apología de la labor de las órdenes religiosas y denunció, con calculado alarmismo, la amovilidad como atentatoria de la existencia de las mismas comunidades monásticas. ${ }^{93}$

Mientras, el clero regular, básicamente agustinos y recoletos, planificaba su estrategia en Manila, y sobre todo en Madrid, a través de sus procuradores, Ce-

\footnotetext{
${ }^{91}$ Gainza explica estos pormenores en su Amovilidad de los curas regulares de las Islas Filipinas. Una copia en APAF, 909/2.

${ }^{92}$ Cuando el 20 de marzo la exposición de los obispos llegó al Consejo de Administración, el gobernador Rafael Echagüe observó que la cuestión era conocida en toda la capital «por motivos extraños a las oficinas». AHN, Ultramar, Filipinas, 2205, Gracia y Justicia, s/n. Manila, 17-V-1864.

${ }_{93}$ Una copia en: Documentos interesantes acerca de la secularización y amovilidad de los curas regulares en Filipinas, Madrid, Imprenta de la viuda de M. Minuesa de los Ríos, 1897. Documento número 9, 36-54.
} 
lestino Mayordomo, agustino, y Guillermo Agudo, recoleto, los presbíteros, liderados por Pedro Peláez, habían iniciado ya sus movimientos para apoyar las peticiones de los obispos.

El doctor Peláez, entonces tesorero de la catedral, hizo suyas esas demandas. Como venía haciendo desde el año anterior, puso en movimiento a sus agentes en Madrid. Junto a él, trabajó Ignacio Ponce de León, amigo suyo, miembro del cabildo y compañero de piso. Ambos tuvieron una fluida correspondencia con sus apoderados en la capital española: básicamente el jurista Lecaros, el más activo de todos ellos, el sobrino de Peláez, el canónigo Agustín Puig, y un tal Miguel Plassard, apoderado de Peláez al menos en 1854, y durante un tiempo delegado de negocios de franciscanos y dominicos. ${ }^{94}$ Todos habrían de estar atentos a las instrucciones que recibiesen.

Los clérigos seculares intentaron atraerse el apoyo de los consejeros que deliberaban sobre la exposición de los tres obispos a través de un papel volante, posteriormente publicado de modo anónimo en Madrid por sus agentes. A pesar de las discrepancias manifestadas por algunos estudiosos, su autoría es debida a Ignacio Ponce de León, que escribía, a inspiración de Peláez, en defensa de las tesis de la movilidad. Según parece, el escrito fue entregado por el mismo Ponce, u otro presbítero, en las casas particulares de los señores consejeros más próximos el día 31 de mayo, es decir cuatro días antes de que su autor muriese en el virulento terremoto que sacudió Manila en junio de $1863 .{ }^{95}$ Más adelante, fue respondido ferozmente por los agustinos Francisco Cuadrado y Diego de la Hoz, ${ }^{96}$ y el

94 Sabemos de la existencia de estos agentes por la información que proporciona Agudo a su provincial. El procurador supo de todos ellos por sus grandes influencias en los organismos de Ultramar. AM Legajo 88, Número 3, Madrid, 3-II-1863. G. Agudo a J. Félix de la Encarnación. Plassard, por su parte, también aparece en los ya citados expedientes personales de Peláez. La única vez que se cita a Lecaros en los documentos propios de Peláez es en una ocasión en su correspondencia con Barili. En ella el nuncio avisa de haber recibido por Lecaros ciertos donativos para el Papa enviados por Pedro Peláez. APP, II-7-023, 36. Madrid, 5-XII-1862. L. Barili a P. Peláez.

95 Actualmente existen escasísimas copias de este texto. Fue publicado de modo anónimo con el siguiente título: Papel volante que un sacerdote del clero secular llevó en persona a domicilio a los miembros del Consejo de Administración, para que en su vista fallasen la exposición de los Señores Diocesanos, como se pide, Madrid, imprenta de la Regeneración, Gravina 21, a cargo de D. F. Gamayo, 1863. No obstante, tanto por documentos encontrados en el APAF (215-3-a; junto al texto aparece escrita a mano la autoría de Ponce así como que fue entregado a los consejeros «cuatro días antes de su muerte»), como en el AHN (2205) -por información dada por el propio arzobispo en carta de 22 de abril de 1864-, se sabe que el autor fue el mencionado miembro del cabildo de la catedral manilense.

${ }^{96}$ Los escritos de Cuadrado y de la Hoz fueron publicados anónimamente. El de Cuadrado, primero de modo individual con el título: Refutación al manuscrito de un Sacerdote Indígena de las Islas Filipinas acerca de la amovilidad de los Curas Regulares. Madrid, Imp. de la compañía de Impresores y Libreros del Reino, 1863; y después en: G. Agudo y C. Mayordomo, Importantísima cuestión..., 34-43, donde aparece la firma con las siglas P.L.C (Padre Lector Cuadrado). Existe otra copia en APAF 215/3, como el de Diego de la Hoz, también citado en I. RoDRíGUEZ, y J. ÁlvAREZ, «Inquietud en la Iglesia de Filipinas», 286-296.

Hispania Sacra, LXIII

128, julio-diciembre 2011, 747-782, ISSN: 0018-215-X 
periódico La Regeneración, que lo tachó -sin duda bajo el aliento de Agudo-, de ser «eco del liberalismo reformador». 97

La cuestión de los curatos había distanciado fuertemente a Peláez de las órdenes religiosas en general, y de los agustinos en particular, con quienes había mantenido una relación de proximidad y cordialidad, como se comprobó, por ejemplo, en la cesión temporal por esta Orden del manuscrito original del Estadismo de Zúñiga para su publicación en El Católico Filipino. ${ }^{98}$

El siguiente movimiento de Peláez fue preparar un libro, Documentos importantes para la cuestión pendiente de curatos en Filipinas. En él se insertaron textos muy favorables a las pretensiones del clero secular: exposiciones del arzobispo Basilio Sancho de Santa Justa y Rufina (1768) en torno a la visita diocesana, y una larga serie de escritos, material y publicaciones en sobre los derechos de la clerecía en la provisión parroquial.

Peláez denostó con toda esa documentación lo fútil de los pretextos del clero regular por seguir aduciendo privilegios ya caducos del siglo XVIII, y, sobre todo, negó la legitimidad y capacidad del clero filipino para trabajar en los curatos. No obstante, y aunque entonces sus detractores no supieron verlo, la argumentación aportada sobre Basilio Sancho podría haber sido refutada recordando simplemente su cambio de actitud a favor del clero regular en la segunda parte de su pontificado. Peláez logró transmitir en su trabajo una fuerte sensación del inmovilismo centenario en los estamentos del clero regular.

Según datos solventes encontrados en la amplia correspondencia de Guillermo Agudo, parece deducirse que, en abril o principios de mayo, el P. Peláez envío el manuscrito a sus agentes en Madrid, posiblemente a través de su sobrino. Llegó en junio, poco después del terremoto. A partir de ese mes, Lecaros realizó, de forma anónima, unas 1.900 copias en la imprenta de El Clamor Público, donde los presbíteros habían publicado años atrás algunos artículos con motivo de la real orden de $1849 .{ }^{99}$

De acuerdo con una carta del provincial recoleto Juan Félix, a finales de octubre aparecieron, muerto ya su autor, los primeros ejemplares en Manila. Su difusión fue prohibida por las autoridades ${ }^{100} \mathrm{El}$ coste de la edición corrió a cargo del cura Agustín de Mendoza, futuro párroco del arrabal de Santa Cruz e im-

${ }^{97}$ APAF 839, 136-137, 120-121. La contestación publicada en La Regeneración es de 5 de agosto de 1863 .

98 I. RoDRÍGUEZ, Historia..., IV, 351-353.

99 Para su autoría vease: W. E. RetanA, Aparato bibliográfico..., II, número 1030.

100 La noticia sobre la participación del sobrino la da Agudo en AM Legajo 88, Número 3. Madrid, 19-XII-1863. G. Agudo J. Félix. Y la de la circulación del folleto por Manila la da el provincial recoleto a su procurador en Madrid en carta de 24 de octubre del mismo año en: Manuel CARCELLER, Historia general de la orden de recoletos de san Agustín, Madrid (1962), XI (años 1837-1866), 582. 
plicado en los sucesos de Cavite. Los comisarios procuradores Agudo y Mayordomo intentaron replicar a Peláez con la publicación en la misma editorial de otros dos libros en defensa de la inamovilidad del clero regular. ${ }^{101}$

Peláez también realizó otro trabajo, manuscrito y no publicado, remitido al nuncio en Madrid el día 22 de mayo, 12 días antes de morir, con el título de Breves apuntes sobre la cuestión de Curatos en Filipinas. ${ }^{102}$ Peláez, según dejaba entrever, quería evitar la pérdida de casi todas las parroquias para los presbíteros filipinos. El escrito era muy similar en su demanda a los Documentos importantes, pero exponiendo, de modo más denso y profundo, su pensamiento y sus propuestas.

En la primavera de 1863, con un ambiente de creciente crispación, la exposición de los obispos fue estudiada en el Consejo de Administración. Entre abril y mayo se elaboraron dos ponencias particulares. La primera, firmada por el filipino Félix Pardo de Tavera, a favor de la amovilidad, y la segunda, por el español José María Alix, en contra. Entre medias, no habían dejado de exacerbarse las opiniones de unos y otros difundidas, con firma o anónimas, por los mentideros, oficinas y sacristías de Manila.

En éstas el 3 de junio se produjo un fuerte temblor en la capital que sacudió todos sus cimientos. Entre las numerosas víctimas se encontraban el tesorero P. Peláez y varios miembros del cabildo -entre ellos Ignacio Ponce de León-, que perecieron aplastados por los cascotes de la catedral mientras atendían las vísperas solemnes de la fiesta del Corpus Christi. ${ }^{103}$

Antes de que se retiraran los escombros, estallaron todas las tensiones acumuladas en los últimos meses. Aquellos que no se habían atrevido a denunciarlo en vida por el gran respeto que imponía-«oráculo» del clero lo llamó en una ocasión el arzobispo-, lo censuraron públicamente aprovechando su desaparición y propalando todo tipo de acusaciones sobre su lealtad.

Un panfleto anónimo titulado Un verdadero español afirmó que de no haber muerto Peláez en el terremoto habría encabezado ese mismo día, junto a los

101 Sus títulos: Importantísima cuestión que puede afectar gravemente a la existencia de las islas Filipinas, Madrid, Imprenta de El Clamor Público, 1863; Complemento de los documentos del folleto de 14 de noviembre de este año de 1863 sobre cuestiones de Curatos, Madrid, Imprenta de El Clamor Público, 1863.

102 Un estudio sobre estos Breves apuntes (Manila, 1863. parte $3^{\circ}$ : Manuscrito existente en ASV, Nunciatura de Madrid. Caja 447) puede verse en A. UY, The State of the Church in the Philippines..., 242-245; Albert Flores, «Pedro Peláez. «Brebes [sic] apuntes sobre la cuestión de curatos de Filipinas»: A transcription», Philippinum 1 (2001), 78-116. Peláez da cuenta del envío al nuncio en carta de 22 de mayo de 1863 (APP, II-7-023, pp. 42-43 a).

103 Para los efectos del terremoto, véase: Ramírez GIRAUDIER, Terremoto de Manila del día 3 de junio de 1863. publicado en el Diario de Manila.

Hispania Sacra, LXIII

128, julio-diciembre 2011, 747-782, ISSN: 0018-215-X 
miembros del cabildo, una insurrección contra España. Sólo los miedos de entonces hicieron explicables que personas incluso próximas a Peláez, como el dominico Treserra o el mismo arzobispo, dieran pábulo a tales rumores providencialistas. ${ }^{104}$ «Sólo bajo presión de esa atmósfera nebulosa y sofocante por el polvo que levantaron las ruinas del terremoto, puede discurrirse y hablarse como se habló» matiza Gainza, que también tuvo sus dudas sobre lo ocurrido. ${ }^{105}$

Las posturas enconadas en torno a la figura de Peláez, su voluntad acérrima en obtener la movilidad, con el propósito de conservar algunas parroquias para el clero filipino, hicieron que algunos contemplaran la cuestión como esencialmente antirreligiosa y antiespañola. Estos temores llevaron al magistrado Emilio Triviño a emitir un voto particular en contra de la famosa exposición de 25 de febrero, y en última estancia, a que Jimeno y Gainza, su primer promotor, retirasen la firma. De esta manera, ambos dominicos dejaron solo al arzobispo ante los más críticos, no quedándole más remedio que pedir su detención el 3 de septiembre. No obstante esto, el asunto se estudió finalmente en el Consejo de Administración del 23 de septiembre, que decidió por 12 votos en contra y 2 a favor la anulación y expediente de la demanda.

El hecho de que los votos en contra fuesen de los ponentes españoles y los favorables de los filipinos (Calvo y Padilla) da idea del significado racial que había adquirido lo que en principio había sido simplemente un punto de legislación canónica. Así lo entendió el arzobispo: «los indígenas prohijaron el pensamiento de los obispos, los peninsulares se declararon sus adversarios; y de esta manera se revistió con cierto ropaje político lo que en el fondo era un punto de mera disciplina eclesiástica». ${ }^{106} \mathrm{~A}$ pesar de la retirada de la exposición, los procuradores de recoletos y agustinos, Agudo y Mayordomo, atacaron sin cesar durante el siguiente año al arzobispo y su programa de reformas en varios periódicos madrileños.

Muerto Peláez, otros, como el español Manuel Peralta, siguieron con su campaña, pero no con la eficacia ni la contundencia de aquel. En los años siguientes, su pensamiento, acción y escritos se convirtieron, por su firmeza y determinación, en los mejores avales de las propuestas del episcopado y sectores reformistas, de la estrategia del mismo arzobispo y de sus herederos del clero secular, principalmente el P. José Burgos. ${ }^{107}$ Gregorio Melitón, entre otras re-

\footnotetext{
${ }^{104}$ AHN, Ultramar, Filipinas, 2255/1, Gracia y Justicia, Manila, 22-VI-1863. G. Melitón al ministro de Guerra y Ultramar; A. UY, The State of the Church in the Philippines..., 246 y 248.

105 APAF 909/2, F. GAÍnZA, Amovilidad de los curas regulares de las islas Filipinas.

106 AHN, Ultramar, Filipinas, 2205 s/n. Gracia y Justicia. Manila, 22-IV-1864. G. Melitón a A. de Castro, ministro de Utramar.

${ }^{107}$ El P. Burgos, junto a otros, estuvo implicado de algún modo en la redacción del famoso manifiesto del clero secular de 27 de junio de 1864 publicado en el periódico La América el 12 de septiem-
} 
formas, hizo de la movilidad y de la anulación de la real orden de 1861 el caballo de batalla de todo su pontificado. Insistió en ello en su correspondencia los diez años siguientes con las autoridades del Ministerio de Ultramar. A pesar de los temores, manifestados inicialmente con respecto a Peláez tras el terremoto, comprendió que todas sus demandas eran justas y necesarias.

Vio, mejor que nadie, cómo el recorte de parroquias de la clerecía estaba incrementando el antagonismo de clase, y hasta el antiespañolismo. En estas controversias había comenzado a forjarse, lenta pero inexorablemente, el espíritu nacional, el «ser filipino» propiamente dicho. Peláez no había tenido una voluntad decidida en ello, pues su acción primitiva fue estrictamente disciplinar y canónica, pero, con su apasionada defensa de las capacidades e igualdad de los presbíteros nativos, criollos, mestizos o indios, acabó siendo inevitablemente uno de sus principales protagonistas. Hoy es indiscutible, como reconoce Schumacher, la línea que une a Peláez con Rizal, a través del P. Burgos y de Paciano Rizal. ${ }^{108}$ Por eso Peláez, y los clérigos de los sesenta, son de algún modo una especie de generación de pre-ilustrados.

Peláez fue una ráfaga de aire fresco en la hermética Iglesia hispano-filipina, una apuesta por su modernidad y futuro en consonancia con los tiempos. Su conciencia y su actuación pusieron al descubierto la necesidad de introducir cambios en la Iglesia insular, mediante la vuelta a su legislación ordinaria y la ineludible reforma del poderoso clero regular, así como la denuncia del patronato más ultramontano. Tras su desaparición, Peláez se convertirá en una voluntad a imitar, un ejemplo a seguir, una ilusión a alcanzar.

\footnotetext{
bre, primero de entidad tras la desaparición de Peláez y heredero directo de su pensamiento. Vease: John Schumacher, «The Burgos Manifiesto: The authentic text and its genuine author», Philippine Studies 54, (2006).

108 Ibidem, 202.

Hispania Sacra, LXIII

128, julio-diciembre 2011, 747-782, ISSN: 0018-215-X
} 